\title{
Aptamers Selected for Recognizing Amyloid $\beta$-Protein-A Case for Cautious Optimism
}

\author{
Farid Rahimi \\ Division of Biomedical Science and Biochemistry, Research School of Biology, The Australian National University, \\ Canberra, ACT 2601, Australia; farid.rahimi@anu.edu.au or z2170549@zmail.unsw.edu.au; Tel.: +61-2-6125-2851 \\ Received: 5 February 2018; Accepted: 22 February 2018; Published: 27 February 2018
}

\begin{abstract}
Aptamers are versatile oligonucleotide ligands used for molecular recognition of diverse targets. However, application of aptamers to the field of amyloid $\beta$-protein $(\mathrm{A} \beta)$ has been limited so far. $A \beta$ is an intrinsically disordered protein that exists in a dynamic conformational equilibrium, presenting time-dependent ensembles of short-lived, metastable structures and assemblies that have been generally difficult to isolate and characterize. Moreover, despite understanding of potential physiological roles of $A \beta$, this peptide has been linked to the pathogenesis of Alzheimer disease, and its pathogenic roles remain controversial. Accumulated scientific evidence thus far highlights undesirable or nonspecific interactions between selected aptamers and different $A \beta$ assemblies likely due to the metastable nature of $A \beta$ or inherent affinity of RNA oligonucleotides to $\beta$-sheet-rich fibrillar structures of amyloidogenic proteins. Accordingly, lessons drawn from A $\beta$-aptamer studies emphasize that purity and uniformity of the protein target and rigorous characterization of aptamers' specificity are important for realizing and garnering the full potential of aptamers selected for recognizing $A \beta$ or other intrinsically disordered proteins. This review summarizes studies of aptamers selected for recognizing different $\mathrm{A} \beta$ assemblies and highlights controversies, difficulties, and limitations of such studies.
\end{abstract}

Keywords: Alzheimer disease; amyloid $\beta$-protein; antibodies; cross-reactions; nucleotide aptamers; oligonucleotide ligands; systematic evolution of ligands by exponential enrichment; specificity; therapeutics

\section{Introduction}

Specifically detecting or recognizing targets of interest-by molecular recognition-is fundamental in many medical and scientific applications. Conventionally, antibodies have been used for detecting antigenic targets, which may include large proteins, small peptides, polysaccharides, lipids, or nucleic acids. Antibodies have been essential for diagnostic or routine clinical assays and immunotherapeutic applications, and in important techniques such as immunohistochemistry, immunoprecipitation, enzyme-linked immunosorbent assay (ELISA), and western blotting. Besides antibodies, however, nucleotide aptamers (oligonucleotide ligands) have emerged since 1990 and progressed rapidly as alternative molecular-recognition tools, offering many useful and novel scientific applications [1-6]. So far, US Food and Drug Administration (FDA) has approved one aptamer drug, Macugen ${ }^{\circledR}$ or generically pegaptanib (Pfizer Pharmaceuticals Group, New York, NY, USA) [7,8], and reportedly, some additional ten aptamers have undergone clinical trials for treating various conditions, including macular degeneration, coagulation, cancer, and inflammation $[5,6]$. The continually increasing number of reports on aptamers published since the initial 1990 publications [9-12] also vouches for the rapid progress of aptamer science. Searching the MEDLINE database through PubMed for the phrase "aptamer or aptamers" returns 328 reports published in the first decade of aptamer research. The same search returns 9459 reports collectively from 2001 to the end of December 2017 (Figure 1). (Related to aptamers, spiegelmers also are synthetic ligand-binding oligonucleotides, but spiegelmers comprise non-natural L-nucleotides [13]). 
"aptamer or aptamers" searched using PubMed

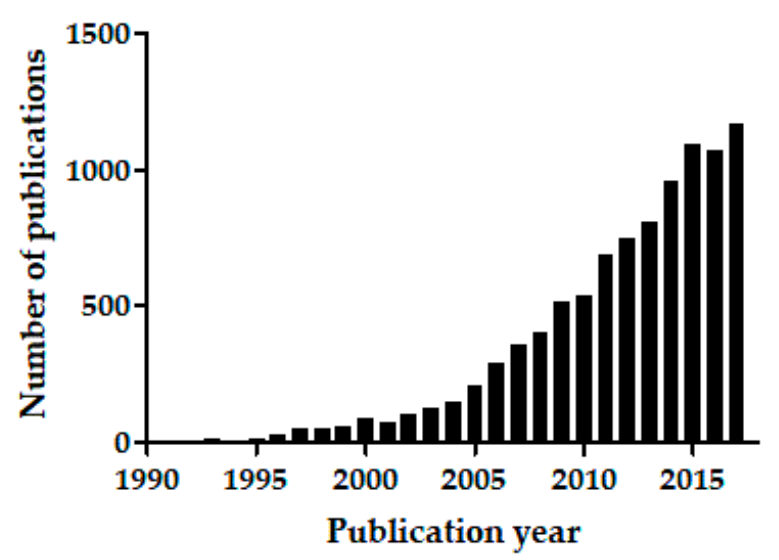

Figure 1. The phrase "aptamer or aptamers" was used as the search term on Pubmed. The number of publications are plotted per publication year.

Importantly, aptamers offer additional advantages that antibodies do not (aptamer advantages and disadvantages have been extensively compared to those of antibodies elsewhere [5]). For example, aptamers effectively cause low or no immunogenicity and can be "selected" for many diverse molecules, including toxic compounds, for which generating antibodies in vivo would likely be impossible. Individual aptamers always interact with a single "aptatope", whereas antibodies could be monoclonal or polyclonal. Moreover, an aptamer's selectivity and specificity for a particular target's aptatope can potentially be tested during the aptamer-selection process in vitro. An antibody's target specificity, however, cannot be ensured because antibodies are generated in vivo, and their capability to distinguish between specific antigenic and less structured epitopes (e.g., polyclonal antibodies) or between conformational epitopes (e.g., monoclonal antibodies) and their closely related molecular structures is determined post facto.

Conformational specificity of antibodies or that of aptamers becomes particularly crucial for targeting intrinsically disordered proteins (IDPs). Many amyloidogenic proteins belong to IDPs [14-16]. IDPs are heterogeneous proteins that exist in a dynamic conformational equilibrium under physiological conditions and present a time-dependent ensemble of short-lived structures that are likely difficult to isolate or stabilize. This conformational behavior, as well as homooligomerization and fibrillization, characterize amyloid $\beta$-protein $(\mathrm{A} \beta)[17,18]$, a metastable, amyloidogenic IDP that is controversially linked to pathogenesis of Alzheimer disease (AD). Some antibodies generated against a certain assembly of $A \beta$ reportedly cross-react with other assemblies of this peptide. Similarly, polyclonal antibodies generated against oligomeric or fibrillar $A \beta$ may cross-react with structurally similar assemblies of other IDPs unrelated to $A \beta[19,20]$. Therefore, specificities of some $A \beta$ antibodies have been unconvincing and disputed [21,22], and studies using such disputed antibodies should be revisited and interpreted carefully. Akin to reports using controversial antibodies or studies using insufficiently characterized antibodies against $A \beta$, collective evidence on aptamers selected for reacting with $A \beta$ highlights undesirable or unexpected interactions despite implementing strict selection experiments. Such studies should also be reconsidered and reviewed carefully.

This review discusses controversies and methodological limitations of using and characterizing aptamers selected for recognizing, mainly, $A \beta$, while alluding to some other relevant studies of A $\beta$-unrelated IDPs. To set the scene and before summarizing aptamer studies relevant to A $\beta$ (in Section 4), I briefly introduce this peptide in Section 2 and write about aptamers and the systematic evolution of ligands by exponential enrichment (SELEX) in Section 3. In Section 5, I highlight the shortcomings of sodium dodecyl sulfate-polyacrylamide gel electrophoresis (SDS-PAGE) in 
characterizing $A \beta$ assemblies and in assessing aptamer/antibody specificities for such assemblies. Finally, I sum up with contextual conclusions.

\section{Amyloid $\beta$-Protein and Alzheimer Disease}

$A \beta$ is produced mainly as $A \beta 40$ or $A \beta 42$ (respectively comprising 40 or 42 amino acid residues) from the amyloid $\beta$-protein precursor (APP), when APP is sequentially cleaved by $\beta$-secretase and $\gamma$-secretase [23,24]. $A \beta$ is produced in its monomeric form as a normal, physiologically relevant peptide [25-34], but it has been studied profusely in pathogenic, protein-misfolding contexts underlying $\mathrm{AD}$. $\mathrm{A} \beta$ 's normal functions and its cytotoxic effects may be regulated by its local concentration; for example, picomolar amounts of synthetic $A \beta 42$ reportedly enhance long-term potentiation and hippocampus-dependent memory in mice, whereas nanomolar levels of the same peptide yield the opposite effects [31]. Long-term potentiation is an electrophysiological paradigm for learning and memory composition, but its role in this capacity has been debated [35]. The above concentration-dependent effects are not unique to $A \beta$ function in the brain. As an aside, S100B, a calcium-binding protein abundant in the brain and implicated in AD pathogenesis [36,37], exerts neurotrophic or neurotoxic effects at nanomolar or micromolar concentrations, respectively [38].

$A \beta^{\prime}$ s pathogenic premises in AD have been based on the classical amyloid cascade hypothesis [39] and its contemporary, revised version [40-42]. The classical amyloid cascade hypothesis posited that overproduction and deposition of $\mathrm{A} \beta$ fibrils in amyloid plaques, the pathological hallmarks of $\mathrm{AD}$, cause $\mathrm{AD}$ and that formation of neurofibrillary tangles (the other $\mathrm{AD}$ hallmark), cell loss, vascular damage, and dementia are direct results of $A \beta$ deposition [39]. The contemporary/revised version of the amyloid cascade hypothesis — the oligomer cascade hypothesis [43] — gives primacy to the neurotoxic and synaptotoxic effects of soluble, prefibrillar oligomeric $A \beta$ assemblies in $A D$ pathogenesis [42]. Therefore, many trials have attempted to target $A \beta$ for therapeutic or diagnostic purposes $[44,45]$. However, the two cascade hypotheses have been consistently debated and challenged [46-49]. Furthermore, since the original observations that $A \beta$ is a major component of plaques in AD-afflicted brains [50-54], and that the plaques contain fibrillar, $\beta$-sheet-rich $A \beta[55,56]$, and since introduction of the revised hypothesis $[40,41]$, diverse but elusive structural assemblies of $A \beta$ have been described and studied profusely in vitro [43,57-60], adding to the complexity of A $\beta$-oligomer literature. These assemblies have been studied or described structurally, functionally, or both, but their interrelationships, and more importantly, their relevance to AD pathogenesis and progression are still enigmatic $[57,60]$ particularly because their undisputed identification or characterization in vivo has been challenging [47].

Importantly, the $A D$ plaque core contains not only $A \beta$-as thought [61-63] — but also other potential products of APP processing [22,64], other proteinaceous and nonproteinaceous components, including glycosaminoglycan, collagen, lipids, metal ions, reactive oxygen species, inflammatory proteins, and nucleic acids [65-77]. These observations suggest that diverse detrimental mechanisms, other than or additional to misfolding or deposition of $A \beta$, may underlie $A D$ pathogenesis or progression. These mechanisms include disruption of cellular metabolism [78,79], deregulation of synapse structure and function [80], membrane damage [81], ionic imbalance [82], oxidative stress [83], inflammatory stress [84-86], and apoptotic [78] or other cytotoxic effects. A $\beta$ by itself is unlikely to be underlying $\mathrm{AD}$ pathogenesis or progression. This is corroborated by the failure or discontinuation of some high-profile clinical trials designed based on the amyloid cascade hypothesis [47], repudiating the notion that $A \beta$ is central to $A D$ pathogenesis. It is likely that targeting of $A \beta$ by some means may disrupt its physiological roles and may not be effective therapeutically in humans [47]. Although this may be an unresolved controversy, the physiological roles of $A \beta$ should be considered when designing $\mathrm{A} \beta$-targeting therapeutics. 


\section{Aptamers and Systematic Evolution of Ligands by Exponential Enrichment}

Aptamers for a target are selected from a pool of random nucleotides by a combinatorial, in vitro molecular-evolution technique termed-SELEX $[9,10,12]$. Two groups first used SELEX to select highly avid and specific RNA aptamers for particular targets, including organic dyes [10] and bacteriophage T4 DNA polymerase [12,87]. Since then, aptamers have been selected for a variety of targets, including metal ions [88], organic molecules [89], amino acids [90-92], viral nucleic acid components [93-96], peptides [97], proteins [5,6,98], drugs [99-101], macromolecules [102-105], cells [106,107], and pathogens [108-113].

SELEX is an iterative process that enables selecting and amplifying a specific property (e.g., avid binding for aptamers, or enzymatic activity for ribozymes or DNAzymes) from a large pool of oligonucleotide sequences, similar to a miniature Darwinian evolution [6,114]. A typical SELEX experiment includes repeated rounds of (1) incubating a library of random oligonucleotide sequences $\left(\sim 10^{13}-10^{15}\right.$ unique sequence in a naïve, unselected pool) with a target molecule; (2) separating target-bound sequences from unbound sequences; (3) dissociating the oligonucleotide-target complexes; and (4) amplifying, identifying, and sequencing the resultant, selected oligonucleotide pool, which contains potentially specific and avid aptamers for the target [114]. Repeated rounds of SELEX are driven by affinity to the target and by competition amongst random sequences. Preselection (negative SELEX) and counter-SELEX (subtractive SELEX) can be interspersed between certain rounds of SELEX respectively to remove sequences that nonspecifically bind to the partitioning matrix or those that bind to molecules closely similar to the actual target [114]. The final oligonucleotide pool becomes enriched with a relatively small number of sequences that, in case of aptamers, bind the target avidly and hopefully specifically. (In case of ribozymes and DNAzymes, sequences with desired catalytic activities are enriched $[115,116]$.) The resultant aptamers can be amplified by polymerase chain reaction (PCR), products of which can then be cloned and sequenced to identify the best binding sequences. Finally, binding affinities, specificities, and cross-reactivity of aptamers are determined [117], and post-SELEX modifications are applied to improve affinity, specificity, stability, pharmacokinetics, or bioavailability of aptamers $[114,118]$.

Since its inception $[10,12,87]$, many variations of SELEX have been developed and used, achieving targeted and specific outcomes [119,120], and SELEX has been optimized and extended to isolation of RNA, single-stranded DNA, or modified versions thereof.

The discriminatory power and specificity of aptamers in some cases are surprisingly high. Aptamers reportedly can discriminate targets based on subtle chemical differences e.g., presence or absence of a methyl/hydroxyl group or chirality ( $R$ vs. $S$ enantiomer). For example, a theophylline-specific aptamer distinguishes it from caffeine-which differs from theophylline by only one methyl group-at least ten-fold more efficiently than an antibody generated for this purpose [121]. Similarly, an enantioselective, modified DNA aptamer could distinguish $(R)$-thalidomide from (S)-thalidomide [122]. Such high levels of aptamer specificity result from the selective pressure achieved by counter-SELEX (subtractive SELEX) [121].

Selecting highly specific aptamers is not always achievable, however. For example, in some cases of cell-SELEX, which uses whole cells for selection, the resultant aptamers recognize both membrane proteins and membrane lipids [123]. As discussed in more detail later, selecting for targeting IDPs may also result in aptamers that cross-react with different structures of a targeted protein. Although determining aptamer specificity is a crucial step in characterizing aptamers, aptamer characterization has rarely been fully considered, especially for aptamers selected for cell-membrane targets [123] and for IDPs such as prion proteins (PrP) [124] or A $\beta$ [125-127]. In the following two sections, I discuss why characterizing aptamer specificity is important in research into $\mathrm{A} \beta$ and, by extension, other IDPs.

\section{Aptamers and $A \beta$}

Aptamer studies using IDPs and amyloidogenic proteins so far show a general tendency for aptamers (and unselected, naïve oligonucleotide libraries) to preferentially bind to $\beta$-sheet-rich 
fibrillar amyloid assemblies despite selection against prefibrillar/nonfibrillar assemblies. For example, several groups have reported aptamers that bind PrP sequences [124,128-134]. An RNA aptamer selected for the recombinant bovine PrP reportedly recognized bovine PrP- $\beta$ [134] —a soluble, oligomeric, $\beta$-sheet-rich conformational variant of full-length $\operatorname{PrP}$ that forms amyloid fibrils [135]. Bunka et al. generated aptamers for monomeric and several forms of fibrillar $\beta 2$-microglobulin [136]. These aptamers were found to bind also fibrils of other amyloidogenic proteins, including apomyoglobin, $A \beta 40$, transthyretin, or lysozyme, in addition to those of $\beta 2$-microglobulin [136]. In the latter study, the naïve library also apparently reacted with long, straight fibrils of $\beta 2$-microglobulin with half the strength of the selected aptamers [136]. Aptamers for $\alpha$-synuclein have been reported and shown to bind strongly to $\alpha$-synuclein oligomers but weakly to its fibrils $[137,138]$. Similar outcomes have been obtained in the context of $A \beta$ as discussed in detail below.

The first study that described RNA aptamers for $A \beta$ used a chemically synthesized monomeric $A \beta 40$ preparation with an additional engineered $N$-terminal cysteine as SELEX target. This preparation was immobilized on a thiopropyl-activated Sepharose 6B matrix by disulfide bonding [125]. Importantly, because $A \beta$ tends to aggregate rapidly, the authors coupled the $A \beta 40$ preparation to Sepharose using 60\% 1,1,1,3,3,3-hexafluoro-2-propanol (HFIP) in $10 \mathrm{mM}$ Tris-HCl, pH 7.7, to keep A $\beta 40$ disaggregated and soluble. (HFIP is used to dissociate self-assembling amyloid proteins $[139,140]$.) The authors used a random 70-nucleotide RNA library ( $10^{15}$ sequences) plus the flanking $5^{\prime}$ and $3^{\prime}$ primer sites. The library was first precleared (negative SELEX) using unloaded Sepharose and then incubated with Sepharose-bound $\mathrm{A} \beta 40$ at $4 \mu \mathrm{M}$ on the resin. After washing the unbound RNA pool, the bound RNA was eluted with $A \beta 40$ by dithiothreitol reduction of the disulfide bond. RNA was extracted, reverse transcribed to DNA, and amplified by PCR. After eight rounds of selection, $\sim 140$ binding sequences were eluted. The aptamers were then characterized by affinity chromatography to measure their dissociation constants, which ranged from 29 to $48 \mathrm{nM}$. Surprisingly, the selected aptamers did not bind soluble $A \beta 40$ as tested by counter-elution using soluble $A \beta 40$ and by mobility-shift assays. The aptamers showed unexpected binding to fibrillar assemblies of A $\beta 40$ as observed by streptavidin-biotin conjugation, gold labeling, and electron microscopy. The authors concluded that $A \beta 40$ may have aggregated on the matrix despite their using HFIP during $A \beta 40$ conjugation to Sepharose [125], and thus selected aptamers bound fibrils nonspecifically.

As another example of aptamers selected for $A \beta$ preparations, aptamers reported by Takahashi et al. so far are the only ones displaying binding affinity to an oligomeric "model" of A $\beta 40$ [126]. The library pool in their study was incubated with $A \beta 40$ conjugated to colloidal gold nanoparticles $(10 \mathrm{~nm}$ diameter) acting as an "A $\beta$ oligomer model," which was described previously [20]. Two aptamers, N2 and E2, could bind this $\mathrm{A} \beta 40$ preparation when incubated at $4{ }^{\circ} \mathrm{C}$ and recognized $\mathrm{A} \beta 40$ in solution by fluorescence anisotropy. $K_{\mathrm{d}}$ values calculated from fluorescence anisotropy studies ranged from 11 to $22 \mu \mathrm{M}$. However, upon aptamer binding saturation with $\sim 50 \mu \mathrm{M} \mathrm{A} \beta 40$, fluorescence anisotropy showed a change of 0.006-0.008 units which may well fall within the noise of such experiments (as discussed elsewhere [141]) despite the authors' argument that this change may have resulted from the small mass of $A \beta 40$. Thus, the reported $K_{d}$ values remain questionable.

Conjugating $A \beta 40$ to gold nanoparticles was first used to imitate spherical oligomers as antigen for generating the oligomer-specific antibody A11 [20]. A11 was found to react specifically with certain oligomeric preparations of $A \beta 40$ and $A \beta 42$ but not soluble, low-molecular-weight $A \beta$ or fibrillar $A \beta$ preparations [20]. Low-molecular-weight $A \beta$ preparations comprise soluble, monomeric $A \beta$ in dynamic equilibrium with low-order $A \beta$ homooligomers [142]. Although arranging $A \beta 40$ monomers on the surface of gold nanoparticles likely mimics high-order A $\beta$ assemblies, and N2 and E2 aptamers likely preferably bound these structures, the ultimate proof of specificity is to exclude cross-reactivity of N2 or E2 aptamers with A $\beta$ fibrils or fibrillar assemblies of other amyloidogenic proteins because of reported cross-reactivity of some "oligomer-specific" antibodies and "oligomer-specific" aptamers with fibrillar amyloid structures [21]. N2 and E2 were not tested for their cross-reactivity with fibrillar assemblies of $A \beta$ or of other amyloidogenic proteins. They were not tested against other oligomeric 
preparations of $A \beta$ or oligomeric preparations of other IDPs either. Similar to the case of N2 and E2, the aptamer M5-15, selected for the amyloidogenic protein, $\alpha$-synuclein, reportedly reacted with monomeric and oligomeric forms of the target protein, but its cross-reactivity with $\alpha$-synuclein fibrils was not tested [138].

Although N2 and E2 aptamers were not tested for their cross-reactivity with fibrillar assemblies of $A \beta 40$ or $A \beta 42$, they reportedly inhibited $A \beta$ fibrillization as observed by ELISA using the $6 E 10$ antibody [126]. (6E10 is a monoclonal antibody raised against residues 1-17 of human A $\beta$ [143-145]). However, the reported ELISA results are surprising because of the following two caveats. First, at the initial time point, 6E10 ELISA did not detect the $\mathrm{A} \beta$ preparation either in the absence or in presence of the two aptamers, contradicting the fact that $6 \mathrm{E} 10$ reportedly reacts with random-coil (or statistical-coil) A $\beta$ monomers $[19,146]$. Thus, at the initial time points, the sample without aptamers should have presented an ELISA signal at least as intense as that with the fibrillar preparation without added aptamers. Secondly, the authors did not exclude the possibility that the aptamers could compete with 6 E10 binding to $A \beta$ under the ELISA conditions. Thus, ELISA results may merely indicate low binding of the $6 \mathrm{E} 10$ antibody to the protein-aptamer mixture because of potential competition between aptamer and $6 \mathrm{E} 10$ for binding to fibrillar $\mathrm{A} \beta$. Nevertheless, $\mathrm{A} \beta$ fibrils were not detected by electron microscopy in the presence of the aptamers; authors reported oligomers, protofibrils, and amorphous aggregates as potential products of fibril disintegration in the presence of aptamers [126]. Whether the abovementioned nonfibrillar $A \beta$ assemblies were cytotoxic or not was not tested. Thus, the full reactivity/specificity spectrum and functions of these aptamers are yet to be confirmed.

Three years later, the N2 aptamer was reported as a conjugate to poly(lactic-co-glycolic acid)coated curcumin (PLGA-curcumin) nanoparticles [147]. Aptamer-PLGA-curcumin nanoparticles were not cytotoxic, taken up by cells, and found to bind A $\beta 42$ fibrils and disintegrate them [147]. Whether the fibril-disintegration products under such experimental conditions were cytotoxic or not was not tested, but the authors concluded that the fibril-degrading effect of curcumin was unaffected by conjugation of the aptamer to the PLGA-curcumin nanoparticles. The authors postulated that the resultant smaller amyloid fragments could easily be cleared by phagocytosis [147]. Interestingly, a recently published review [148] cites the above study, "... the N2 aptamer conjugated to curcumin-polymer nanoparticles enhanced binding to, and disaggregated, amyloid plaques, which were then cleared by phagocytosis", misleading the reader by misreporting that actual "amyloid plaques" were used and "phagocytosis assays" were done in the original study [147]. Taking both studies $[126,147]$ together, it is unclear whether the N2 aptamer or curcumin or both could bind A 342 fibrils (not plaques as mentioned [148], which are the in vivo hallmarks of AD) and degrade them because both activities were seemingly attributed to curcumin and N2. Importantly, curcumin along with resveratrol and epigallocatechin-3-gallate (reviewed [149]) have been dubbed as pan-assay-interfering compounds $[150,151]$, and conclusions made about these three polyphenols in the AD literature in relation to their effects on $\mathrm{A} \beta$ should be reassessed carefully [152].

We asked why aptamers selected for monomeric or prefibrillar assemblies of amyloidogenic proteins recognized their polymeric, fibrillar forms. Could specific aptamers for monomeric and/or oligomeric forms of an amyloidogenic protein ever be obtained? What are the implications of fibril reactivity of RNA or DNA aptamers? To answer these questions, we performed SELEX to obtain aptamers that could potentially recognize the covalently stabilized trimeric A $\beta 40$ [153], which were produced by using photo-induced crosslinking of unmodified proteins (PICUP) [154,155], extracted from gels subjected to SDS-PAGE, and purified by removing SDS [156]. We also used a mixture of low-molecular-weight oligomeric A $\beta 40$, which was generated by PICUP but not exposed to SDS at all, in later experiments. (The significance of SDS effects on A $\beta$ preparations is discussed below).

I summarize the main findings of that study: (1) aptamers selected for purified, covalently stabilized trimeric $A \beta 40$ failed to react with purified $A \beta 40$ trimers or with the low-molecular-weight mixture of prefibrillar $A \beta 40$ assemblies, but they reacted with $A \beta 40$ or $A \beta 42$ fibrils, as confirmed by dot blotting. (2) Aptamers selected for recognizing trimeric $A \beta 40$ reacted not only with $A \beta$ 
fibrils, but also with fibrils of other amyloidogenic proteins, including calcitonin, islet amyloid polypeptide (IAPP), insulin, lysozyme, and prion $106-126$. (3) Our aptamers reacted with fibrils of the tested amyloidogenic proteins similarly to $\beta$ aptamers selected for $A \beta 40$ previously [125] and reused/retested for imaging $A \beta$ plaques [127]. (4) To exclude the possibility of SDS contamination in our trimeric $A \beta 40$ preparation, we used a PICUP-generated mixture of low-molecular-weight $A \beta 40$ preparation, which was not subjected to SDS-PAGE. As discussed below, SDS is known to accelerate $A \beta$ self-assembly and $\beta$-sheet formation [157]. In these series of SELEX experiments, we included two counter-SELEX cycles against A $\beta 40$ fibrils after the fourth and fifth SELEX cycles. The RNA pool obtained after the fifth SELEX cycle reacted with fibrils of $A \beta$ and fibrils of the other tested amyloidogenic proteins similarly to our aptamers [153] and $\beta$ aptamers selected previously [125]. This finding indicated that counter-selection against $A \beta 40$ fibrils could not effectively remove aptamer reactivity with fibrils. (5) Because of this finding, we performed another SELEX cycle with several counter-SELEX experiments using A $\beta 40$ fibrils aiming to obtain an RNA pool devoid of fibril-binding sequences. However, five consecutive rounds of counter-SELEX using excess $A \beta 40$ fibrils failed to reduce the binding of the RNA pool to $A \beta 40$ fibrils. (6) Because of the persistent and apparently non-specific binding of RNA aptamers to amyloid fibrils, and because counter-SELEX using A $\beta 40$ fibrils failed to abrogate aptamer binding to amyloid fibrils, we assessed our naïve RNA library and a G-biased RNA library for their reactivity with amyloid fibrils. We used the biased library with reduced G ratio (A:C:G:T $=30 \%: 30 \%: 10 \%: 30 \%$ ) because our sequencing and motif analyses showed high G content in selected aptamers. We found that both naïve RNA libraries reacted with fibrillar assemblies of the same proteins akin to all the selected aptamers we tested [153]. (7) The selected aptamers-and the naïve library—could track progression of $\beta$-sheet formation and fibrillization in $A \beta 40$ and insulin with $\sim 16$-fold higher sensitively than the thioflavin $\mathrm{T}$ fluorescence assay, which is commonly used to assess fibril formation by many amyloidogenic proteins $[158,159]$. (8) HFIP-treated lysozyme and IAPP contained sufficient $\beta$-sheet content as inferred from their recognition by the tested aptamers and the naïve library. Our observation of non-specific reactivity with fibrils of selected and tested aptamers, which is reminiscent of similar findings in previous studies $[62,125,134,136]$, suggest that aptamers (and naïve libraries of oligonucleotides) likely recognize potentially common aptatopes $[62,153,160]$.

Studies that selected aptamers for recognizing $A \beta$ assemblies are summarized in Table 1.

Table 1. Aptamers selected for interacting with different amyloid $\beta$-protein $(\mathrm{A} \beta)$ preparations.

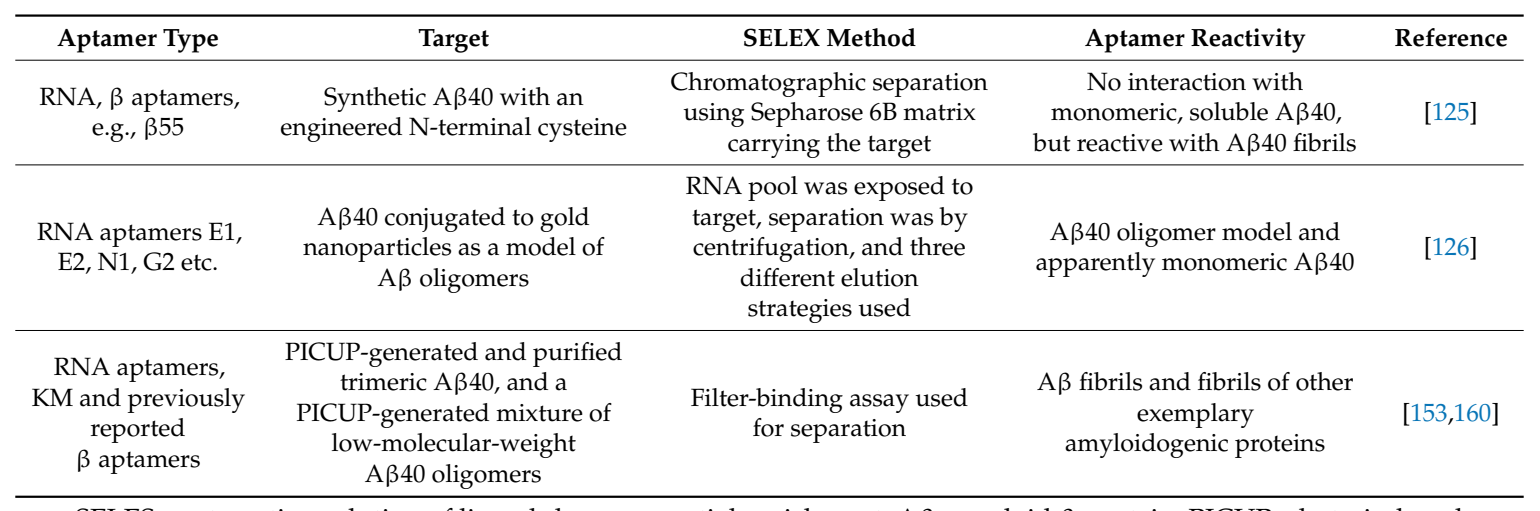

SELES, systematic evolution of ligands by exponential enrichment; $A \beta$, amyloid $\beta$-protein; PICUP, photo-induced crosslinking of unmodified proteins.

Farrar et al. [127] used the $\beta 55$ aptamer, which was published [125] and retested [153] previously, for ex vivo imaging of frozen sections of human AD brain fixed in paraformaldehyde, while including the corresponding reverse sequence of $\beta 55$ as control. The authors performed in vivo multiphoton microscopy using the APP-PS1 transgenic mouse model of AD [161] to visualize plaques [127]. Biotinylated $\beta 55$ reportedly stained many more plaques than its reverse sequence, and $\beta 55$ staining localized with thioflavin-S signal, confirming staining of amyloid plaques 
ex vivo [127], and by inference confirming binding to $A \beta$ fibrils as shown by previous studies $[125,160]$. Fluorescein-conjugated $\beta 55$ stained amyloid plaques and amyloid angiopathic lesions in brains of APP-PS1 mice visualized by multiphoton microscopy [127]. In localization staining experiments, $\beta 55$ and methoxy-X04 stained the dense core of the plaques, whereas $\beta 55$ additionally stained a diffuse halo surrounding the plaque cores [127]. (Methoxy-X04 is a derivative of Congo Red and it has been used previously for optical imaging of AD mouse models [162]. Congo Red is used to stain and detect amyloid depositions in tissues. Upon binding to amyloid structures, Congo Red yields a unique blue-green birefringence under a cross-polarized light microscope [159].) Farrar et al. [127] concluded that $\beta 55$ may have bound smaller aggregates, including oligomers, of $A \beta$ peripheral to the dense plaques based on their observation that $\beta 55$ apparently bound low-molecular-weight oligomers of $A \beta 40$ and A $\beta 42$ on SDS-PAGE gels, and similar observation reported by Koffie et al. [163], showing a "halo of oligomers" surrounding the plaques detected by a so-called "conformation-specific" NAB61 antibody [164]. However, Farrar et al. [127] did not test nor compared the sensitivity of methoxy-X04 with that of $\beta 55$ for binding small, early, $\beta$-sheet-containing fibrillar aggregates of $A \beta$. Possibly, methoxy-X04 could not sensitively detect the small $\beta$-sheet-containing fibrillar A $\beta$ similarly to thioflavin $T$, which failed to detect early, sparse $A \beta 40$ and insulin fibrils, but RNA aptamers detected early fibrillar assemblies of $A \beta 40$ and insulin containing $\beta$-sheet structure [153]. Implications of $\beta 55$ aptamer binding to SDS-fractionated A $\beta$ species and Farrar's conclusions about $\beta 55$ 's ability to detect oligomeric $\mathrm{A} \beta$ species around $\mathrm{A} \beta$ plaques are discussed in more detail in the following section.

\section{SDS-PAGE, Aptamers, Antibodies, and "Halos of Oligomers"}

Along with silver staining, Coomassie staining, western blotting, or mass spectrometry, SDS-PAGE has been used to identify proteins and examine protein oligomerization, size distribution, or protein-protein interactions. However, SDS $\left(288.38 \mathrm{~g} \cdot \mathrm{mol}^{-1}\right)$ does not affect all proteins identically [165] because different proteins, different conformations of a protein [166], or fragments of certain proteins [167] may not bind SDS at stoichiometric amounts (though SDS generally binds different proteins at an approximately constant mass-mass ratio-1.4 g SDS per gram of polypeptide [159]). Furthermore, in certain cases, SDS induces or stabilizes-rather than disrupting-secondary or quaternary structures $[166,168,169]$. In some other cases, SDS may induce homo-oligomerization or conversely dissociate protein complexes [169-172]. For example, both human and rat $\alpha$-synuclein show aberrant electrophoretic mobility and SDS-PAGE-induced high-molecular-mass components, which do not exist in the samples when analyzed by size-exclusion chromatography [173].

$\mathrm{A} \beta$ is an amphipathic protein that forms "SDS-stable oligomers" [174,175]. In fact, SDS-induced aggregation of $A \beta$ has facilitated extraction of $A \beta$ from brain homogenates [176]. $A \beta 42$-derived "globulomers" are in vitro model oligomeric species produced by incubating A $\beta 42$ with $0.2 \%$ SDS $[177,178]$. A $\beta$ aggregates rapidly after being treated with SDS and forms high-molecular-mass assemblies [157]. During electrophoresis of A $\beta 40$, its SDS-induced aggregates dissociate and only a monomeric component is observed by staining, whereas electrophoresis of $A \beta 42$ yields apparently trimeric and tetrameric components as observed previously $[179,180]$. In addition, essentially identical monomer-trimer-tetramer components appear when different $\mathrm{A} \beta 42$ preparations, including monomeric, oligomeric, or fibrillar A $\beta 42$, are subjected to SDS-PAGE [181], demonstrating that SDS treatment, and electrophoresis in the presence of SDS-rather than the initial assembly state-determines A $\beta 42$ 's apparent PAGE mobility. After treatment in a urea-containing SDS-PAGE system, $A \beta$ and its truncated versions defy the mass-mobility relationships, because A $\beta-S D S$ interaction likely does not relate to the number of constituent amino acids but to the sum of hydrophobicity indices [167]. An exemplary study of A $\beta 40$ dimers stabilized by an intermolecular disulfide bridge showed the same SDS-PAGE profile before and after formation of $\beta$-sheet-rich A $\beta$ protofibrils [182]. Watt et al. compared SDS-PAGE, the $\mathrm{XMAP}^{\circledR}$ multiplex immunoassay (Luminex, Madison, WI, USA) and surface-enhanced laser desorption/ionization time-of-flight mass spectrometry when examining $A \beta$ extracted from human cortical tissues [183]. Their mass-spectrometry experiments 
could not detect oligomers, while monomeric and dimeric $A \beta$ components appeared through SDS-PAGE; surprisingly, the apparent monomeric and dimeric A $\beta$ levels increased with increasing SDS concentrations in the sample buffer [183]. Thus, electrophoretic separation and detection of monomeric or oligomeric assemblies in an $\mathrm{A} \beta$ preparation do not necessarily prove that such components exist in the sample before SDS-PAGE.

The shortcomings of SDS-PAGE have been highlighted in many studies of A $\beta[21,60,157,159$, $179,181,183$ ] and $\alpha$-synuclein [173] and is gradually being appreciated in the AD field. Meanwhile, interpretations of findings about elusive $A \beta$ oligomers has come under scrutiny and disputed to such an extent that the foundations of the oligomer cascade hypothesis have been shaken. Accordingly, a relatively recent study has critically evaluated the use of SDS-PAGE, claiming that the concept of A $\beta$ oligomers has disserved decades of research into AD [184]. This study used ion mobility coupled with electrospray-ionization mass spectrometry (ESI-IM-MS), challenging the biophysical paradigms dominating the A $\beta$ field based on SDS-PAGE and PICUP analyses of prefibrillar assemblies of $A \beta$. When coupled with MS, ion-mobility spectrometry, which distinguishes ions according to both their mass-to-charge ratio and their three-dimensional structures, is a useful analytical technique for examining covalent or non-covalent protein structures in complex mixtures. Ion-mobility spectrometry-mass spectrometer (IMS-MS) can resolve molecules of identical mass-to-charge ratios with differing collision cross-sections (e.g., different assembly states or conformations) and/or differing charge states [159]. Pujol-Pina et al. used PICUP-stabilized A $\beta$ oligomers and showed that the A $\beta 42$ pentamer-hexamer components observed by SDS-PAGE following PICUP are methodological artifacts [184]. The authors removed the SDS-PAGE step from analyzing PICUP-generated, cross-linked $A \beta 40$ and $A \beta 42$ preparations and, instead, used size-exclusion chromatography and ESI-IM-MS. Since initial PICUP-SDS-PAGE observations, A $\beta 40$ and A $\beta 42$ were thought to oligomerize and aggregate through distinct pathways [154,179]; that is, A $\beta 42$ was thought to aggregate through formation of "paranuclei" — the pentamer-hexamer subunits—and distinctly from $A \beta 40$, which was thought to aggregate through dimer-trimer-tetramer subunits. By excluding SDS-PAGE, ESI-IM-MS showed no differences in the oligomer-size distribution between cross-linked or uncross-linked $A \beta 40$ and $A \beta 42$, suggesting that $A \beta 40$ and $A \beta 42$ predominantly and similarly initiate oligomerization and aggregation through dimer-trimer subunits [184]. The implications of the ESI-IM-MS findings controverts the conclusions that C-terminal length of $A \beta$ was the most important structural determinant in early oligomerization, and the side-chains of Ile41 and Ala42 in $A \beta 42$ were important both for effective formation of paranuclei and for their self-association $[179,185]$. It was discussed previously that differences in toxicity between $A \beta 40$ and $A \beta 42$ [186] correlate with PICUP-SDS-PAGE observations that paranuclei are produced by A $\beta 42$ only, confirming the correlation of the latter to AD pathogenesis.

As another example, the elaborate study by Koffie et al., which used ultrathin array tomography and immunofluorescence, claimed that senile plaques in brains of AD model mice are surrounded by "haloes of oligomeric A $\beta$ " [163]. This conclusion was mainly based on immunoreactivity of NAB61, which apparently reacted with oligomeric $A \beta$ assemblies fractionated by SDS-PAGE [164]. The original paper, which described this antibody as a "Conformation-selective Monoclonal Antibody," ironically reported that NAB61 also recognized synthetic $A \beta$ fibrils by electron microscopy, as presented in its small Figure 4B panel [164]. Considering these caveats, one may rightly question the major conclusions drawn by Koffie et al. [163], and the same interpretative analogies repeated and drawn by Farrar et al. [127]. The former used NAB61 and the latter $\beta 55$ and claimed that the antibody and aptamer were specific for SDS-PAGE-fractionated oligomeric A $\beta$ and, in this capacity, detected A $\beta$ oligomers around plaques, ignoring the shortcomings of SDS-PAGE (firstly) and the fact that $\beta 55$ and NAB61 both cross-react with fibrillar A $\beta$ assemblies besides SDS-fractionated A $\beta$ species (secondly). Similar cross-reactivity was apparent in antibodies that were produced and characterized after iterative immunization of beagles [187] with an aggregated A $\beta$ preparation [188]. Thus, the conclusions by Farrar et al. [127] about staining small oligomers haloing the dense plaques as observed by $\beta 55$ must 
be reexamined in light of the collective literature regarding (1) SDS-PAGE analysis of A $\beta$; (2) NAB61 reactivity with $A \beta$ assemblies; (3) plaque immunohistochemistry; (4) and sensitivity of the aptamer binding compared to methoxy-X04 (or thioflavin T/S) binding to A $\beta$ fibrils-and plaques.

To sum up, despite its wide use and resolution, SDS-PAGE and western blotting are not reliable methods for determining oligomer sizes or assembly states of certain IDPs, e.g., $\alpha$-synuclein and $A \beta$ oligomers. As such, SDS-PAGE is not suitable for assessing the specificity or selectivity of aptamers (or antibodies) for A $\beta$ preparations. Considering SDS-PAGE's shortcomings is important for characterizing the reactivity and specificity of aptamers or antibodies generated against $A \beta$ species (see $[127,163,164])$ because SDS-induced oligomers in an A $\beta$ preparation are not necessarily structurally the same as those potentially present in the absence of SDS [184].

\section{Conclusions}

The conclusions from this review are manifold.

- The handful of reports published since 2002 on aptamers developed for targeting A $\beta$ have led to important and instructive findings. RNA and DNA aptamers and random nucleotide libraries used for selecting aptamers are found to react inherently and nonspecifically with fibrillar $A \beta$ preparations and exemplary amyloid assemblies $[21,153,160]$. Most likely, the aptamer-targeted common aptatope in these cases is the backbone of the proteins in a cross- $\beta$ structure because this protein structure reportedly facilitates retention of RNAs and RNA-binding proteins into special ribonucleoprotein complexes, including stress granules and RNA-processing organelles [189]. The inherent and persistent tendency of RNA aptamers to bind amyloid fibrils (or vice versa) may explain entrapment of RNA in the senile plaques and neurofibrillary tangles [73-75], the two pathological hallmarks of AD brains. Moreover, amyloid fibrils and oligonucleotides act as polyelectrolytes and interact by electrostatic forces [190]. These $\beta$-sheet-mediated, polyelectrolytic, protein-oligonucleotide interactions were thought to be vital for support, stability, compartmentalization, protection, and resistance to degradation in the harsh environments of the antediluvian, prebiotic world [191], indicating an ancient phenomenon. Interaction of RNA aptamers with amyloid fibrils have implications for the previous and future studies of aptamers selected for amyloidogenic proteins and conclusions drawn from such studies.

- Attributing oligomer specificity to an aptamer based on results obtained by SDS-PAGE fractionation of $A \beta$ preparations disregards the collected evidence on the unsuitability of SDS-PAGE for analyzing and size estimation of amyloidogenic protein assemblies.

- Attributing oligomer specificity to an aptamer (or an antibody) that evidently binds fibrillar structures of amyloidogenic proteins (see $[127,163]$ ) is erroneous and misleading; thus, binding specificities of such aptamers in tissue sections do not represent their true specificities and enhances the illusion about presence of $A \beta$ oligomers in tissue sections.

- Implications of SDS-PAGE are extendable to studies whereby prefibrillar amyloid assemblies were extracted and studied in vitro [192-199] or PICUP-stabilized oligomers were studied to establish the biophysical paradigms of $A \beta$ oligomerization $[179,184,185]$.

- Finally, I hope this review could encourage the aptamer-amyloid-Alzheimer researchers, the relevant funding bodies, these fields' peer-reviewers, and the fields' young scholars to scrutinize and study the relevant literature deeply before enthusing [148,200-202] about aptamers in the context of $A \beta$ research. Let us not generate an aptamer field akin to the muddled assortment of antibodies promoted in AD research [21,22].

Acknowledgments: The author acknowledges the helpful comments by Susan Howitt, Division of Biomedical Science and Biochemistry, Research School of Biology, The Australian National University.

Conflicts of Interest: The author declares no conflict of interest. 


\section{Abbreviations}

$\begin{array}{ll}\text { A } \beta & \text { amyloid } \beta \text {-protein } \\ \text { AD } & \text { Alzheimer disease } \\ \text { APP } & \text { amyloid } \beta \text {-protein precursor } \\ \text { ELISA } & \text { enzyme-linked immunosorbent assay } \\ \text { ESI-IM-MS } & \text { ion mobility coupled with electrospray-ionization mass spectrometry } \\ \text { HFIP } & \text { 1,1,1,3,3,3-hexafluoro-2-propanol } \\ \text { IAPP } & \text { islet amyloid polypeptide } \\ \text { IDPs } & \text { intrinsically disordered proteins } \\ \text { IM-MS } & \text { ion-mobility spectrometry-mass spectrometery } \\ \text { PCR } & \text { polymerase chain reaction } \\ \text { PICUP } & \text { photo-induced crosslinking of unmodified proteins } \\ \text { PLGA } & \text { poly(lactic-co-glycolic acid) } \\ \text { PrP } & \text { prion proteins } \\ \text { SDS-PAGE } & \text { sodium dodecyl sulfate-polyacrylamide gel electrophoresis } \\ \text { SELEX } & \text { systematic evolution of ligands by exponential enrichment }\end{array}$

\section{References}

1. Jayasena, S.D. Aptamers: An emerging class of molecules that rival antibodies in diagnostics. Clin. Chem. 1999, 45, 1628-1650. [PubMed]

2. Famulok, M.; Mayer, G. Aptamers as tools in molecular biology and immunology. Curr. Top. Microbiol. Immunol. 1999, 243, 123-136. [PubMed]

3. Tan, W.; Wang, H.; Chen, Y.; Zhang, X.; Zhu, H.; Yang, C.; Yang, R.; Liu, C. Molecular aptamers for drug delivery. Trends Biotechnol. 2011, 29, 634-640. [CrossRef] [PubMed]

4. Ni, X.; Castanares, M.; Mukherjee, A.; Lupold, S.E. Nucleic acid aptamers: Clinical applications and promising new horizons. Curr. Med. Chem. 2011, 18, 4206-4214. [CrossRef] [PubMed]

5. Zhou, J.; Rossi, J. Aptamers as targeted therapeutics: Current potential and challenges. Nat. Rev. Drug Discov. 2017, 16, 181-202. [CrossRef] [PubMed]

6. Zhuo, Z.; Yu, Y.; Wang, M.; Li, J.; Zhang, Z.; Liu, J.; Wu, X.; Lu, A.; Zhang, G.; Zhang, B. Recent advances in SELEX technology and aptamer applications in biomedicine. Int. J. Mol. Sci. 2017, 18. [CrossRef] [PubMed]

7. Siddiqui, M.A.; Keating, G.M. Pegaptanib: In exudative age-related macular degeneration. Drugs 2005, 65, 1571-1577; discussion 1578-1579. [CrossRef] [PubMed]

8. Ng, E.W.; Shima, D.T.; Calias, P.; Cunningham, E.T., Jr.; Guyer, D.R.; Adamis, A.P. Pegaptanib, a targeted anti-VEGF aptamer for ocular vascular disease. Nat. Rev. Drug Discov. 2006, 5, 123-132. [CrossRef] [PubMed]

9. Oliphant, A.R.; Brandl, C.J.; Struhl, K. Defining the sequence specificity of DNA-binding proteins by selecting binding sites from random-sequence oligonucleotides: Analysis of yeast GCN4 protein. Mol. Cell. Biol. 1989, 9, 2944-2949. [CrossRef] [PubMed]

10. Ellington, A.D.; Szostak, J.W. In vitro selection of RNA molecules that bind specific ligands. Nature 1990, 346, 818-822. [CrossRef] [PubMed]

11. Robertson, D.L.; Joyce, G.F. Selection in vitro of an RNA enzyme that specifically cleaves single-stranded DNA. Nature 1990, 344, 467-468. [CrossRef] [PubMed]

12. Tuerk, C.; Gold, L. Systematic evolution of ligands by exponential enrichment: RNA ligands to bacteriophage T4 DNA polymerase. Science 1990, 249, 505-510. [CrossRef] [PubMed]

13. Vater, A.; Klussmann, S. Turning mirror-image oligonucleotides into drugs: The evolution of Spiegelmer ${ }^{\circledR}$ therapeutics. Drug Discov. Today 2015, 20, 147-155. [CrossRef] [PubMed]

14. Uversky, V.N. Targeting intrinsically disordered proteins in neurodegenerative and protein dysfunction diseases: Another illustration of the $\mathrm{D}^{2}$ concept. Expert Rev. Proteom. 2010, 7, 543-564. [CrossRef] [PubMed]

15. Ambadipudi, S.; Zweckstetter, M. Targeting intrinsically disordered proteins in rational drug discovery. Expert Opin. Drug Discov. 2016, 11, 65-77. [CrossRef] [PubMed]

16. Basu, S.; Bahadur, R.P. A structural perspective of RNA recognition by intrinsically disordered proteins. Cell. Mol. Life Sci. 2016, 73, 4075-4084. [CrossRef] [PubMed] 
17. Korsak, M.; Kozyreva, T. Beta Amyloid hallmarks: From intrinsically disordered proteins to Alzheimer's disease. Adv. Exp. Med. Biol. 2015, 870, 401-421. [CrossRef] [PubMed]

18. Hoshino, M. Fibril formation from the amyloid- $\beta$ peptide is governed by a dynamic equilibrium involving association and dissociation of the monomer. Biophys. Rev. 2017, 9, 9-16. [CrossRef] [PubMed]

19. Kayed, R.; Head, E.; Sarsoza, F.; Saing, T.; Cotman, C.W.; Necula, M.; Margol, L.; Wu, J.; Breydo, L.; Thompson, J.L.; et al. Fibril specific, conformation dependent antibodies recognize a generic epitope common to amyloid fibrils and fibrillar oligomers that is absent in prefibrillar oligomers. Mol. Neurodegener. 2007, 2, 18. [CrossRef] [PubMed]

20. Kayed, R.; Head, E.; Thompson, J.L.; McIntire, T.M.; Milton, S.C.; Cotman, C.W.; Glabe, C.G. Common structure of soluble amyloid oligomers implies common mechanism of pathogenesis. Science 2003, 300, 486-489. [CrossRef] [PubMed]

21. Rahimi, F.; Bitan, G. Overview of fibrillar and oligomeric assemblies of amyloidogenic proteins. In Non-Fibrillar Amyloidogenic Protein Assemblies—Common Cytotoxins Underlying Degenerative Diseases; Rahimi, F., Bitan, G., Eds.; Springer: Dordrecht, The Netherlands, 2012; pp. 1-36, ISBN 978-9-40-072773-1.

22. Hunter, S.; Brayne, C. Do anti-amyloid beta protein antibody cross reactivities confound Alzheimer disease research? J. Negat. Results Biomed. 2017, 16, 1. [CrossRef] [PubMed]

23. Esler, W.P.; Wolfe, M.S. A portrait of Alzheimer secretases-New features and familiar faces. Science 2001, 293, 1449-1454. [CrossRef] [PubMed]

24. Martins, R.N.; Robinson, P.J.; Chleboun, J.O.; Beyreuther, K.; Masters, C.L. The molecular pathology of amyloid deposition in Alzheimer's disease. Mol. Neurobiol. 1991, 5, 389-398. [CrossRef] [PubMed]

25. Haass, C.; Hung, A.Y.; Schlossmacher, M.G.; Oltersdorf, T.; Teplow, D.B.; Selkoe, D.J. Normal cellular processing of the $\beta$-amyloid precursor protein results in the secretion of the amyloid $\beta$ peptide and related molecules. Ann. N. Y. Acad. Sci. 1993, 695, 109-116. [CrossRef] [PubMed]

26. Parihar, M.S.; Brewer, G.J. Amyloid- $\beta$ as a modulator of synaptic plasticity. J. Alzheimers Dis. 2010, 22, 741-763. [CrossRef] [PubMed]

27. Puzzo, D.; Arancio, O. Amyloid- $\beta$ peptide: Dr. Jekyll or Mr. Hyde? J. Alzheimers Dis. 2013, 33, S111-S120. [CrossRef] [PubMed]

28. Carrillo-Mora, P.; Luna, R.; Colín-Barenque, L. Amyloid beta: Multiple mechanisms of toxicity and only some protective effects? Oxid. Med. Cell. Longev. 2014, 2014, 795375. [CrossRef] [PubMed]

29. Dawkins, E.; Small, D.H. Insights into the physiological function of the $\beta$-amyloid precursor protein: Beyond Alzheimer's disease. J. Neurochem. 2014, 129, 756-769. [CrossRef] [PubMed]

30. Martorana, A.; Di Lorenzo, F.; Belli, L.; Sancesario, G.; Toniolo, S.; Sallustio, F.; Sancesario, G.M.; Koch, G. Cerebrospinal fluid $A \beta_{42}$ levels: When physiological become pathological state. CNS Neurosci. Ther. 2015, 21, 921-925. [CrossRef] [PubMed]

31. Fedele, E.; Rivera, D.; Marengo, B.; Pronzato, M.A.; Ricciarelli, R. Amyloid $\beta$ : Walking on the dark side of the moon. Mech. Ageing Dev. 2015, 152, 1-4. [CrossRef] [PubMed]

32. Gupta, A.; Goyal, R. Amyloid beta plaque: A culprit for neurodegeneration. Acta Neurol. Belg. 2016, 116, 445-450. [CrossRef] [PubMed]

33. Chen, G.F.; Xu, T.H.; Yan, Y.; Zhou, Y.R.; Jiang, Y.; Melcher, K.; Xu, H.E. Amyloid beta: Structure, biology and structure-based therapeutic development. Acta Pharmacol. Sin. 2017, 38, 1205-1235. [CrossRef] [PubMed]

34. Alkasir, R.; Li, J.; Li, X.; Jin, M.; Zhu, B. Human gut microbiota: The links with dementia development. Protein Cell 2017, 8, 90-102. [CrossRef] [PubMed]

35. Dudai, Y. Molecular bases of long-term memories: A question of persistence. Curr. Opin. Neurobiol. 2002, 12, 211-216. [CrossRef]

36. Mrak, R.E.; Griffin, W.S. The role of activated astrocytes and of the neurotrophic cytokine S100B in the pathogenesis of Alzheimer's disease. Neurobiol. Aging 2001, 22, 915-922. [CrossRef]

37. Wilcock, D.M.; Griffin, W.S. Down's syndrome, neuroinflammation, and Alzheimer neuropathogenesis. J. Neuroinflamm. 2013, 10, 84. [CrossRef] [PubMed]

38. Donato, R. S100: A multigenic family of calcium-modulated proteins of the EF-hand type with intracellular and extracellular functional roles. Int. J. Biochem. Cell Biol. 2001, 33, 637-668. [CrossRef]

39. Hardy, J.A.; Higgins, G.A. Alzheimer's disease: The amyloid cascade hypothesis. Science 1992, 256, $184-185$. [CrossRef] [PubMed]

40. Hardy, J. Testing times for the "amyloid cascade hypothesis". Neurobiol. Aging 2002, 23, 1073-1074. [CrossRef] 
41. Selkoe, D.J.; American College of Physicians; American Physiological Society. Alzheimer disease: Mechanistic understanding predicts novel therapies. Ann. Intern. Med. 2004, 140, 627-638. [CrossRef] [PubMed]

42. Haass, C.; Selkoe, D.J. Soluble protein oligomers in neurodegeneration: Lessons from the Alzheimer's amyloid $\beta$-peptide. Nat. Rev. Mol. Cell Biol. 2007, 8, 101-112. [CrossRef] [PubMed]

43. Hayden, E.Y.; Teplow, D.B. Amyloid $\beta$-protein oligomers and Alzheimer's disease. Alzheimers Res. Ther. 2013, 5, 60. [CrossRef] [PubMed]

44. van Dyck, C.H. Anti-amyloid- $\beta$ monoclonal antibodies for Alzheimer's disease: Pitfalls and promise. Biol. Psychiatry 2017. [CrossRef] [PubMed]

45. Hung, S.Y.; Fu, W.M. Drug candidates in clinical trials for Alzheimer's disease. J. Biomed. Sci. 2017, $24,47$. [CrossRef] [PubMed]

46. Clark, I.A.; Vissel, B. Amyloid $\beta$ : One of three danger-associated molecules that are secondary inducers of the proinflammatory cytokines that mediate Alzheimer's disease. Br. J. Pharmacol. 2015, 172, 3714-3727. [CrossRef] [PubMed]

47. Morris, G.P.; Clark, I.A.; Vissel, B. Inconsistencies and controversies surrounding the amyloid hypothesis of Alzheimer's disease. Acta Neuropathol. Commun. 2014, 2, 135. [CrossRef] [PubMed]

48. Clark, I.A.; Alleva, L.M.; Vissel, B. The roles of TNF in brain dysfunction and disease. Pharmacol. Ther. 2010, 128, 519-548. [CrossRef] [PubMed]

49. Clark, I.A.; Vissel, B. Excess cerebral TNF causing glutamate excitotoxicity rationalizes treatment of neurodegenerative diseases and neurogenic pain by anti-TNF agents. J. Neuroinflamm. 2016, 13, 236. [CrossRef] [PubMed]

50. Glenner, G.G.; Wong, C.W. Alzheimer's disease and Down's syndrome: Sharing of a unique cerebrovascular amyloid fibril protein. Biochem. Biophys. Res. Commun. 1984, 122, 1131-1135. [CrossRef]

51. Glenner, G.G.; Wong, C.W. Alzheimer's disease: Initial report of the purification and characterization of a novel cerebrovascular amyloid protein. Biochem. Biophys. Res. Commun. 1984, 120, 885-890. [CrossRef]

52. Glenner, G.G.; Wong, C.W.; Quaranta, V.; Eanes, E.D. The amyloid deposits in Alzheimer's disease: Their nature and pathogenesis. Appl. Pathol. 1984, 2, 357-369. [PubMed]

53. Masters, C.L.; Multhaup, G.; Simms, G.; Pottgiesser, J.; Martins, R.N.; Beyreuther, K. Neuronal origin of a cerebral amyloid: Neurofibrillary tangles of Alzheimer's disease contain the same protein as the amyloid of plaque cores and blood vessels. EMBO J. 1985, 4, 2757-2763. [PubMed]

54. Masters, C.L.; Simms, G.; Weinman, N.A.; Multhaup, G.; McDonald, B.L.; Beyreuther, K. Amyloid plaque core protein in Alzheimer disease and Down syndrome. Proc. Natl. Acad. Sci. USA 1985, 82, 4245-4249. [CrossRef] [PubMed]

55. Narang, H.K. High-resolution electron microscopic analysis of the amyloid fibril in Alzheimer's disease. J Neuropathol. Exp. Neurol. 1980, 39, 621-631. [CrossRef] [PubMed]

56. Merz, P.A.; Wisniewski, H.M.; Somerville, R.A.; Bobin, S.A.; Masters, C.L.; Iqbal, K. Ultrastructural morphology of amyloid fibrils from neuritic and amyloid plaques. Acta Neuropathol. 1983, 60, 113-124. [CrossRef] [PubMed]

57. Rahimi, F.; Shanmugam, A.; Bitan, G. Structure-function relationships of pre-fibrillar protein assemblies in Alzheimer's disease and related disorders. Curr. Alzheimer Res. 2008, 5, 319-341. [CrossRef] [PubMed]

58. Roychaudhuri, R.; Yang, M.; Hoshi, M.M.; Teplow, D.B. Amyloid $\beta$-protein assembly and Alzheimer disease. J. Biol. Chem. 2009, 284, 4749-4753. [CrossRef] [PubMed]

59. Benilova, I.; Karran, E.; De Strooper, B. The toxic A $\beta$ oligomer and Alzheimer's disease: An emperor in need of clothes. Nat. Neurosci. 2012, 15, 349-357. [CrossRef] [PubMed]

60. Rahimi, F.; Bitan, G. Methods for studying and structure-function relationships of non-fibrillar protein assemblies in Alzheimer's disease and related disorders. In Advances in Alzheimer Research; Lahiri, D.K., Ed.; Bentham Science Publishers: Sharjah, United Arab Emirates, 2014; Volume 2, pp. 291-374, ISBN 978-1-60-805853-2.

61. Söderberg, L.; Bogdanovic, N.; Axelsson, B.; Winblad, B.; Näslund, J.; Tjernberg, L.O. Analysis of single Alzheimer solid plaque cores by laser capture microscopy and nanoelectrospray/tandem mass spectrometry. Biochemistry 2006, 45, 9849-9856. [CrossRef] [PubMed]

62. Mitkevich, O.V.; Kochneva-Pervukhova, N.V.; Surina, E.R.; Benevolensky, S.V.; Kushnirov, V.V.; Ter-Avanesyan, M.D. DNA aptamers detecting generic amyloid epitopes. Prion 2012, 6, 400-406. [CrossRef] [PubMed] 
63. Rüfenacht, P.; Güntert, A.; Bohrmann, B.; Ducret, A.; Döbeli, H. Quantification of the A $\beta$ peptide in Alzheimer's plaques by laser dissection microscopy combined with mass spectrometry. J. Mass Spectrom. 2005, 40, 193-201. [CrossRef] [PubMed]

64. Wirths, O.; Walter, S.; Kraus, I.; Klafki, H.W.; Stazi, M.; Oberstein, T.J.; Ghiso, J.; Wiltfang, J.; Bayer, T.A.; Weggen, $\mathrm{S}$. N-truncated $\mathrm{A} \beta_{4-x}$ peptides in sporadic Alzheimer's disease cases and transgenic Alzheimer mouse models. Alzheimers Res. Ther. 2017, 9, 80. [CrossRef] [PubMed]

65. Panchal, M.; Gaudin, M.; Lazar, A.N.; Salvati, E.; Rivals, I.; Ayciriex, S.; Dauphinot, L.; Dargere, D.; Auzeil, N.; Masserini, M.; et al. Ceramides and sphingomyelinases in senile plaques. Neurobiol. Dis. 2014, 65, 193-201. [CrossRef] [PubMed]

66. Panchal, M.; Loeper, J.; Cossec, J.C.; Perruchini, C.; Lazar, A.; Pompon, D.; Duyckaerts, C. Enrichment of cholesterol in microdissected Alzheimer's disease senile plaques as assessed by mass spectrometry. J. Lipid Res. 2010, 51, 598-605. [CrossRef] [PubMed]

67. Alexandrescu, A.T. Amyloid accomplices and enforcers. Protein Sci. 2005, 14, 1-12. [CrossRef] [PubMed]

68. Liao, L.; Cheng, D.; Wang, J.; Duong, D.M.; Losik, T.G.; Gearing, M.; Rees, H.D.; Lah, J.J.; Levey, A.I.; Peng, J. Proteomic characterization of postmortem amyloid plaques isolated by laser capture microdissection. J. Biol. Chem. 2004, 279, 37061-37068. [CrossRef] [PubMed]

69. Hadley, K.C.; Rakhit, R.; Guo, H.; Sun, Y.; Jonkman, J.E.; McLaurin, J.; Hazrati, L.N.; Emili, A.; Chakrabartty, A. Determining composition of micron-scale protein deposits in neurodegenerative disease by spatially targeted optical microproteomics. eLife 2015, 4. [CrossRef] [PubMed]

70. Shepherd, C.E.; Goyette, J.; Utter, V.; Rahimi, F.; Yang, Z.; Geczy, C.L.; Halliday, G.M. Inflammatory S100A9 and S100A12 proteins in Alzheimer's disease. Neurobiol. Aging 2006, 27, 1554-1563. [CrossRef] [PubMed]

71. Sokolova, A.; Hill, M.D.; Rahimi, F.; Warden, L.A.; Halliday, G.M.; Shepherd, C.E. Monocyte chemoattractant protein-1 plays a dominant role in the chronic inflammation observed in Alzheimer's disease. Brain Pathol. 2009, 19, 392-398. [CrossRef] [PubMed]

72. Atwood, C.S.; Martins, R.N.; Smith, M.A.; Perry, G. Senile plaque composition and posttranslational modification of amyloid- $\beta$ peptide and associated proteins. Peptides 2002, 23, 1343-1350. [CrossRef]

73. Ginsberg, S.D.; Galvin, J.E.; Chiu, T.S.; Lee, V.M.; Masliah, E.; Trojanowski, J.Q. RNA sequestration to pathological lesions of neurodegenerative diseases. Acta Neuropathol. 1998, 96, 487-494. [CrossRef] [PubMed]

74. Ginsberg, S.D.; Crino, P.B.; Hemby, S.E.; Weingarten, J.A.; Lee, V.M.; Eberwine, J.H.; Trojanowski, J.Q. Predominance of neuronal mRNAs in individual Alzheimer's disease senile plaques. Ann. Neurol. 1999, 45, 174-181. [CrossRef]

75. Marcinkiewicz, M. $\beta$ APP and furin mRNA concentrates in immature senile plaques in the brain of Alzheimer patients. J. Neuropathol. Exp. Neurol. 2002, 61, 815-829. [CrossRef] [PubMed]

76. Hirschfield, G.M.; Hawkins, P.N. Amyloidosis: New strategies for treatment. Int. J. Biochem. Cell Biol. 2003, 35, 1608-1613. [CrossRef]

77. Drummond, E.; Nayak, S.; Faustin, A.; Pires, G.; Hickman, R.A.; Askenazi, M.; Cohen, M.; Haldiman, T.; Kim, C.; Han, X.; et al. Proteomic differences in amyloid plaques in rapidly progressive and sporadic Alzheimer's disease. Acta Neuropathol. 2017, 133, 933-954. [CrossRef] [PubMed]

78. Gerakis, Y.; Hetz, C. Emerging roles of ER stress in the etiology and pathogenesis of Alzheimer's disease. FEBS J. 2017. [CrossRef] [PubMed]

79. Gibas, K.J. The starving brain: Overfed meets undernourished in the pathology of mild cognitive impairment (MCI) and Alzheimer's disease (AD). Neurochem. Int. 2017, 110, 57-68. [CrossRef] [PubMed]

80. Yang, Q.; Song, D.; Qing, H. Neural changes in Alzheimer's disease from circuit to molecule: Perspective of optogenetics. Neurosci. Biobehav. Rev. 2017, 79, 110-118. [CrossRef] [PubMed]

81. De Groot, N.S.; Burgas, M.T. Is membrane homeostasis the missing link between inflammation and neurodegenerative diseases? Cell. Mol. Life Sci. 2015, 72, 4795-4805. [CrossRef] [PubMed]

82. Budimir, A. Metal ions, Alzheimer's disease and chelation therapy. Acta Pharm. 2011, 61, 1-14. [CrossRef] [PubMed]

83. Petrou, A.L.; Terzidaki, A. A meta-analysis and review examining a possible role for oxidative stress and singlet oxygen in diverse diseases. Biochem. J. 2017, 474, 2713-2731. [CrossRef] [PubMed]

84. Bagyinszky, E.; Giau, V.V.; Shim, K.; Suk, K.; An, S.S.A.; Kim, S. Role of inflammatory molecules in the Alzheimer's disease progression and diagnosis. J. Neurol. Sci. 2017, 376, 242-254. [CrossRef] [PubMed] 
85. Rojas-Gutierrez, E.; Muñoz-Arenas, G.; Treviño, S.; Espinosa, B.; Chavez, R.; Rojas, K.; Flores, G.; Díaz, A.; Guevara, J. Alzheimer's disease and metabolic syndrome: A link from oxidative stress and inflammation to neurodegeneration. Synapse 2017. [CrossRef] [PubMed]

86. Santos, L.E.; Ferreira, S.T. Crosstalk between endoplasmic reticulum stress and brain inflammation in Alzheimer's disease. Neuropharmacology 2017. [CrossRef] [PubMed]

87. Tuerk, C.; Eddy, S.; Parma, D.; Gold, L. Autogenous translational operator recognized by bacteriophage T4 DNA polymerase. J. Mol. Biol. 1990, 213, 749-761. [CrossRef]

88. Wrzesinski, J.; Jóźwiakowski, S.K. Structural basis for recognition of $\mathrm{Co}^{2+}$ by RNA aptamers. FEBS J. 2008, 275, 1651-1662. [CrossRef] [PubMed]

89. Kim, Y.S.; Niazi, J.H.; Chae, Y.J.; Ko, U.R.; Gu, M.B. Aptamers-in-liposomes for selective and multiplexed capture of small organic compounds. Macromol. Rapid Commun. 2011, 32, 1169-1173. [CrossRef] [PubMed]

90. Yang, X.; Bing, T.; Mei, H.; Fang, C.; Cao, Z.; Shangguan, D. Characterization and application of a DNA aptamer binding to L-tryptophan. Analyst 2011, 136, 577-585. [CrossRef] [PubMed]

91. Kuwahara, M.; Ohsawa, K.; Kasamatsu, T.; Shoji, A.; Sawai, H.; Ozaki, H. Screening of a glutamic acid-binding aptamer from arginine-modified DNA library. Nucleic Acids Symp. Ser. 2005, 81-82. [CrossRef] [PubMed]

92. Ames, T.D.; Breaker, R.R. Bacterial aptamers that selectively bind glutamine. RNA Biol. 2011, 8, 82-89. [CrossRef] [PubMed]

93. Darfeuille, F.; Hansen, J.B.; Orum, H.; Di Primo, C.; Toulmé, J.J. LNA/DNA chimeric oligomers mimic RNA aptamers targeted to the TAR RNA element of HIV-1. Nucleic Acids Res. 2004, 32, 3101-3107. [CrossRef] [PubMed]

94. Lebars, I.; Richard, T.; Di Primo, C.; Toulmé, J.J. NMR structure of a kissing complex formed between the TAR RNA element of HIV-1 and a LNA-modified aptamer. Nucleic Acids Res. 2007, 35, 6103-6114. [CrossRef] [PubMed]

95. Lebars, I.; Richard, T.; Di Primo, C.; Toulmé, J.J. LNA derivatives of a kissing aptamer targeted to the trans-activating responsive RNA element of HIV-1. Blood Cells Mol. Dis. 2007, 38, 204-209. [CrossRef] [PubMed]

96. Sekkai, D.; Dausse, E.; Di Primo, C.; Darfeuille, F.; Boiziau, C.; Toulmé, J.J. In vitro selection of DNA aptamers against the HIV-1 TAR RNA hairpin. Antisense Nucleic Acid Drug Dev. 2002, 12, 265-274. [CrossRef] [PubMed]

97. Bruno, J.G.; Carrillo, M.P.; Phillips, T. Development of DNA aptamers to a foot-and-mouth disease peptide for competitive FRET-based detection. J. Biomol. Tech. 2008, 19, 109-115. [PubMed]

98. Ashrafuzzaman, M. Aptamers as both drugs and drug-carriers. BioMed Res. Int. 2014, $2014,697923$. [CrossRef] [PubMed]

99. Du, Y.; Chen, C.; Yin, J.; Li, B.; Zhou, M.; Dong, S.; Wang, E. Solid-state probe based electrochemical aptasensor for cocaine: A potentially convenient, sensitive, repeatable, and integrated sensing platform for drugs. Anal. Chem. 2010, 82, 1556-1563. [CrossRef] [PubMed]

100. Du, Y.; Chen, C.; Zhou, M.; Dong, S.; Wang, E. Microfluidic electrochemical aptameric assay integrated on-chip: A potentially convenient sensing platform for the amplified and multiplex analysis of small molecules. Anal. Chem. 2011, 83, 1523-1529. [CrossRef] [PubMed]

101. Kawano, R.; Osaki, T.; Sasaki, H.; Takinoue, M.; Yoshizawa, S.; Takeuchi, S. Rapid detection of a cocaine-binding aptamer using biological nanopores on a chip. J. Am. Chem. Soc. 2011, 133, 8474-8477. [CrossRef] [PubMed]

102. Boese, B.J.; Breaker, R.R. In vitro selection and characterization of cellulose-binding DNA aptamers. Nucleic Acids Res. 2007, 35, 6378-6388. [CrossRef] [PubMed]

103. Boese, B.J.; Corbino, K.; Breaker, R.R. In vitro selection and characterization of cellulose-binding RNA aptamers using isothermal amplification. Nucleosides Nucleotides Nucleic Acids 2008, 27, 949-966. [CrossRef] [PubMed]

104. Kim, J.P.; Kwon, I.K.; Sim, S.J. The strategy of signal amplification for ultrasensitive detection of hIgE based on aptamer-modified poly(di-acetylene) supramolecules. Biosens. Bioelectron. 2011, 26, 4823-4827. [CrossRef] [PubMed]

105. Kim, J.P.; Park, C.H.; Sim, S.J. Aptamer biosensors for label-free colorimetric detection of human IgE based on polydiacetylene (PDA) supramolecules. J. Nanosci. Nanotechnol. 2011, 11, 4269-4274. [CrossRef] [PubMed] 
106. Strahm, Y.; Flueckiger, A.; Billinger, M.; Meier, P.; Mettler, D.; Weisser, S.; Schaffner, T.; Hess, O. Endothelial-cell-binding aptamer for coating of intracoronary stents. J. Invasive Cardiol. 2010, 22, 481-487. [PubMed]

107. Thiel, K.W.; Hernandez, L.I.; Dassie, J.P.; Thiel, W.H.; Liu, X.; Stockdale, K.R.; Rothman, A.M.; Hernandez, F.J.; McNamara, J.O., II; Giangrande, P.H. Delivery of chemo-sensitizing siRNAs to HER2 ${ }^{+}$-breast cancer cells using RNA aptamers. Nucleic Acids Res. 2012, 40, 6319-6337. [CrossRef] [PubMed]

108. Thiel, K.W.; Giangrande, P.H. Therapeutic applications of DNA and RNA aptamers. Oligonucleotides 2009, 19, 209-222. [CrossRef] [PubMed]

109. Jyoti, A.; Vajpayee, P.; Singh, G.; Patel, C.B.; Gupta, K.C.; Shanker, R. Identification of environmental reservoirs of nontyphoidal salmonellosis: Aptamer-assisted bioconcentration and subsequent detection of Salmonella Typhimurium by quantitative polymerase chain reaction. Environ. Sci. Technol. 2011, 45, 8996-9002. [CrossRef] [PubMed]

110. Cui, Z.Q.; Ren, Q.; Wei, H.P.; Chen, Z.; Deng, J.Y.; Zhang, Z.P.; Zhang, X.E. Quantum dot-aptamer nanoprobes for recognizing and labeling influenza A virus particles. Nanoscale 2011, 3, 2454-2457. [CrossRef] [PubMed]

111. Ellenbecker, M.; Sears, L.; Li, P.; Lanchy, J.M.; Lodmell, J.S. Characterization of RNA aptamers directed against the nucleocapsid protein of Rift Valley fever virus. Antiviral Res. 2012, 93, 330-339. [CrossRef] [PubMed]

112. Feng, H.; Beck, J.; Nassal, M.; Hu, K.H. A SELEX-screened aptamer of human hepatitis B virus RNA encapsidation signal suppresses viral replication. PLoS ONE 2011, 6, e27862. [CrossRef] [PubMed]

113. Park, S.Y.; Kim, S.; Yoon, H.; Kim, K.B.; Kalme, S.S.; Oh, S.; Song, C.S.; Kim, D.E. Selection of an antiviral RNA aptamer against hemagglutinin of the subtype H5 avian influenza virus. Nucleic Acid Ther. 2011, 21, 395-402. [CrossRef] [PubMed]

114. Stoltenburg, R.; Reinemann, C.; Strehlitz, B. SELEX-A (r)evolutionary method to generate high-affinity nucleic acid ligands. Biomol. Eng. 2007, 24, 381-403. [CrossRef] [PubMed]

115. Diafa, S.; Hollenstein, M. Generation of aptamers with an expanded chemical repertoire. Molecules 2015, 20, 16643-16671. [CrossRef] [PubMed]

116. Hollenstein, M. DNA catalysis: The chemical repertoire of DNAzymes. Molecules 2015, 20, 20777-20804. [CrossRef] [PubMed]

117. Tan, S.Y.; Acquah, C.; Sidhu, A.; Ongkudon, C.M.; Yon, L.S.; Danquah, M.K. SELEX modifications and bioanalytical techniques for aptamer-target binding characterization. Crit. Rev. Anal. Chem. 2016, 46, 521-537. [CrossRef] [PubMed]

118. Gao, S.; Zheng, X.; Jiao, B.; Wang, L. Post-SELEX optimization of aptamers. Anal. Bioanal. Chem. 2016, 408, 4567-4573. [CrossRef] [PubMed]

119. Huang, Z.; Wen, W.; Wu, A.; Niu, L. Chemically modified, $\alpha$-amino-3-hydroxy-5-methyl-4-isoxazole (AMPA) receptor RNA aptamers designed for in vivo use. ACS Chem. Neurosci. 2017, 8, 2437-2445. [CrossRef] [PubMed]

120. Pfeiffer, F.; Rosenthal, M.; Siegl, J.; Ewers, J.; Mayer, G. Customised nucleic acid libraries for enhanced aptamer selection and performance. Curr. Opin. Biotechnol. 2017, 48, 111-118. [CrossRef] [PubMed]

121. Jenison, R.D.; Gill, S.C.; Pardi, A.; Polisky, B. High-resolution molecular discrimination by RNA. Science 1994, 263, 1425-1429. [CrossRef] [PubMed]

122. Shoji, A.; Kuwahara, M.; Ozaki, H.; Sawai, H. Modified DNA aptamer that binds the (R)-isomer of a thalidomide derivative with high enantioselectivity. J. Am. Chem. Soc. 2007, 129, 1456-1464. [CrossRef] [PubMed]

123. Janas, T.; Janas, T. The selection of aptamers specific for membrane molecular targets. Cell. Mol. Biol. Lett. 2011, 16, 25-39. [CrossRef] [PubMed]

124. Macedo, B.; Cordeiro, Y. Unraveling prion protein interactions with aptamers and other PrP-binding nucleic acids. Int. J. Mol. Sci. 2017, 18. [CrossRef]

125. Ylera, F.; Lurz, R.; Erdmann, V.A.; Fürste, J.P. Selection of RNA aptamers to the Alzheimer's disease amyloid peptide. Biochem. Biophys. Res. Commun. 2002, 290, 1583-1588. [CrossRef] [PubMed]

126. Takahashi, T.; Tada, K.; Mihara, H. RNA aptamers selected against amyloid $\beta$-peptide (A $\beta)$ inhibit the aggregation of A $\beta$. Mol. Biosyst. 2009, 5, 986-991. [CrossRef] [PubMed]

127. Farrar, C.T.; William, C.M.; Hudry, E.; Hashimoto, T.; Hyman, B.T. RNA aptamer probes as optical imaging agents for the detection of amyloid plaques. PLoS ONE 2014, 9, e89901. [CrossRef] [PubMed] 
128. Weiss, S.; Proske, D.; Neumann, M.; Groschup, M.H.; Kretzschmar, H.A.; Famulok, M.; Winnacker, E.L. RNA aptamers specifically interact with the prion protein PrP. J. Virol. 1997, 71, 8790-8797. [PubMed]

129. Rhie, A.; Kirby, L.; Sayer, N.; Wellesley, R.; Disterer, P.; Sylvester, I.; Gill, A.; Hope, J.; James, W.; Tahiri-Alaoui, A. Characterization of 2'-fluoro-RNA aptamers that bind preferentially to disease-associated conformations of prion protein and inhibit conversion. J. Biol. Chem. 2003, 278, 39697-39705. [CrossRef] [PubMed]

130. Takemura, K.; Wang, P.; Vorberg, I.; Surewicz, W.; Priola, S.A.; Kanthasamy, A.; Pottathil, R.; Chen, S.G.; Sreevatsan, S. DNA aptamers that bind to $\operatorname{PrP}^{C}$ and not $\operatorname{PrP}^{\mathrm{Sc}}$ show sequence and structure specificity. Exp. Biol. Med. 2006, 231, 204-214. [CrossRef]

131. Bibby, D.F.; Gill, A.C.; Kirby, L.; Farquhar, C.F.; Bruce, M.E.; Garson, J.A. Application of a novel in vitro selection technique to isolate and characterise high affinity DNA aptamers binding mammalian prion proteins. J. Virol. Methods 2008, 151, 107-115. [CrossRef] [PubMed]

132. King, D.J.; Safar, J.G.; Legname, G.; Prusiner, S.B. Thioaptamer interactions with prion proteins: Sequence-specific and non-specific binding sites. J. Mol. Biol. 2007, 369, 1001-1014. [CrossRef] [PubMed]

133. Proske, D.; Gilch, S.; Wopfner, F.; Schätzl, H.M.; Winnacker, E.L.; Famulok, M. Prion-protein-specific aptamer reduces $\mathrm{PrP}^{\mathrm{Sc}}$ formation. ChemBioChem 2002, 3, 717-725. [CrossRef]

134. Murakami, K.; Nishikawa, F.; Noda, K.; Yokoyama, T.; Nishikawa, S. Anti-bovine prion protein RNA aptamer containing tandem GGA repeat interacts both with recombinant bovine prion protein and its $\beta$ isoform with high affinity. Prion 2008, 2, 73-80. [CrossRef] [PubMed]

135. Lührs, T.; Zahn, R.; Wüthrich, K. Amyloid formation by recombinant full-length prion proteins in phospholipid bicelle solutions. J. Mol. Biol. 2006, 357, 833-841. [CrossRef] [PubMed]

136. Bunka, D.H.; Mantle, B.J.; Morten, I.J.; Tennent, G.A.; Radford, S.E.; Stockley, P.G. Production and characterization of RNA aptamers specific for amyloid fibril epitopes. J. Biol. Chem. 2007, 282, 34500-34509. [CrossRef] [PubMed]

137. Tsukakoshi, K.; Abe, K.; Sode, K.; Ikebukuro, K. Selection of DNA aptamers that recognize $\alpha$-synuclein oligomers using a competitive screening method. Anal. Chem. 2012, 84, 5542-5547. [CrossRef] [PubMed]

138. Tsukakoshi, K.; Harada, R.; Sode, K.; Ikebukuro, K. Screening of DNA aptamer which binds to $\alpha$-synuclein. Biotechnol. Lett. 2010, 32, 643-648. [CrossRef] [PubMed]

139. Burdick, D.; Soreghan, B.; Kwon, M.; Kosmoski, J.; Knauer, M.; Henschen, A.; Yates, J.; Cotman, C.; Glabe, C. Assembly and aggregation properties of synthetic Alzheimer's A4/ $\beta$ amyloid peptide analogs. J. Biol. Chem. 1992, 267, 546-554. [PubMed]

140. Stine, W.B.; Jungbauer, L.; Yu, C.; LaDu, M.J. Preparing synthetic A $\beta$ in different aggregation states. Methods Mol. Biol. 2011, 670, 13-32. [CrossRef] [PubMed]

141. Mahood, R.A. Selection of RNA Aptamers and Their Recognition of Amyloid Assemblies. Ph.D. Thesis, The University of Leeds, Leeds, UK, 2015.

142. Teplow, D.B. Preparation of amyloid $\beta$-protein for structural and functional studies. Methods Enzymol. 2006, 413, 20-33. [CrossRef] [PubMed]

143. Kim, K.S.; Miller, D.L.; Sapienza, V.J.; Chen, C.M.J.; Bai, C.; Grundke-Iqbal, I.; Currie, J.R.; Wisniewski, H.M. Production and characterization of monoclonal antibodies reactive to synthetic cerebrovascular amyloid peptide. Neurosci. Res. Commun. 1988, 2, 121-130.

144. Kim, K.S.; Wen, G.Y.; Bancher, C.; Chen, C.M.J.; Sapienza, V.J.; Hong, H.; Wisniewski, H.M. Detection and quantitation of amyloid $\beta$-peptide with two monoclonal antibodies. Neurosci. Res. Commun. 1990, 7, 113-122.

145. Pirttilä, T.; Kim, K.S.; Mehta, P.D.; Frey, H.; Wisniewski, H.M. Soluble amyloid $\beta$-protein in the cerebrospinal fluid from patients with Alzheimer's disease, vascular dementia and controls. J. Neurol. Sci. 1994, 127, 90-95. [CrossRef]

146. Necula, M.; Kayed, R.; Milton, S.; Glabe, C.G. Small molecule inhibitors of aggregation indicate that amyloid $\beta$ oligomerization and fibrillization pathways are independent and distinct. J. Biol. Chem. 2007, 282, 10311-10324. [CrossRef] [PubMed]

147. Mathew, A.; Aravind, A.; Brahatheeswaran, D.; Fukuda, T.; Nagaoka, Y.; Hasumura, T.; Iwai, S.; Morimoto, H.; Yoshida, Y.; Maekawa, T.; et al. Amyloid-binding aptamer conjugated curcumin-PLGA nanoparticle for potential use in Alzheimer's disease. BioNanoScience 2012, 2, 83-93. [CrossRef]

148. Chakravarthy, M.; Chen, S.; Dodd, P.R.; Veedu, R.N. Nucleic acid-based theranostics for tackling Alzheimer's disease. Theranostics 2017, 7, 3933-3947. [CrossRef] [PubMed] 
149. Rahimi, F.; Li, H.; Sinha, S.; Bitan, G. Modulators of Amyloid $\beta$-Protein (A $\beta$ ) Self-Assembly. In Developing Therapeutics for Alzheimer's Diseas; Wolfe, M.S., Ed.; Academic Press: Boston, MA, USA, 2016; pp. 97-191, ISBN 978-0-12-802173-6.

150. Baell, J.; Walters, M.A. Chemical con artists foil drug discovery. Nature 2014, 513, 481-483. [CrossRef] [PubMed]

151. Nelson, K.M.; Dahlin, J.L.; Bisson, J.; Graham, J.; Pauli, G.F.; Walters, M.A. The essential medicinal chemistry of curcumin. J. Med. Chem. 2017, 60, 1620-1637. [CrossRef] [PubMed]

152. Bahadori, F.; Demiray, M. A realistic view on "the essential medicinal chemistry of curcumin". ACS Med. Chem. Lett. 2017, 8, 893-896. [CrossRef] [PubMed]

153. Rahimi, F.; Murakami, K.; Summers, J.L.; Chen, C.H.B.; Bitan, G. RNA aptamers generated against oligomeric A $\beta 40$ recognize common amyloid aptatopes with low specificity but high sensitivity. PLoS ONE 2009, 4, e7694. [CrossRef] [PubMed]

154. Bitan, G.; Lomakin, A.; Teplow, D.B. Amyloid $\beta$-protein oligomerization: Prenucleation interactions revealed by photo-induced cross-linking of unmodified proteins. J. Biol. Chem. 2001, 276, 35176-35184. [CrossRef] [PubMed]

155. Rahimi, F.; Maiti, P.; Bitan, G. Photo-induced cross-linking of unmodified proteins (PICUP) applied to amyloidogenic peptides. J. Vis. Exp. 2009. [CrossRef] [PubMed]

156. Rosensweig, C.; Ono, K.; Murakami, K.; Lowenstein, D.K.; Bitan, G.; Teplow, D.B. Preparation of stable amyloid $\beta$-protein oligomers of defined assembly order. Methods Mol. Biol. 2012, 849, 23-31. [CrossRef] [PubMed]

157. Bitan, G.; Fradinger, E.A.; Spring, S.M.; Teplow, D.B. Neurotoxic protein oligomers-What you see is not always what you get. Amyloid 2005, 12, 88-95. [CrossRef] [PubMed]

158. LeVine, H., 3rd. Quantification of $\beta$-sheet amyloid fibril structures with thioflavin T. Methods Enzymol. 1999, 309, 274-284. [PubMed]

159. Li, H.; Rahimi, F.; Sinha, S.; Maiti, P.; Bitan, G.; Murakami, K. Amyloids and Protein Aggregation-Analytical Methods. In Encyclopedia of Analytical Chemistry; John Wiley \& Sons, Ltd.: Hoboken, NJ, USA, 2009, ISBN 9780470027318.

160. Rahimi, F.; Bitan, G. Selection of aptamers for amyloid $\beta$-protein, the causative agent of Alzheimer's disease. J. Vis. Exp. 2010. [CrossRef] [PubMed]

161. Jankowsky, J.L.; Fadale, D.J.; Anderson, J.; Xu, G.M.; Gonzales, V.; Jenkins, N.A.; Copeland, N.G.; Lee, M.K.; Younkin, L.H.; Wagner, S.L.; et al. Mutant presenilins specifically elevate the levels of the 42 residue $\beta$-amyloid peptide in vivo: Evidence for augmentation of a 42 -specific $\gamma$ secretase. Hum. Mol. Genet. 2004, 13, 159-170. [CrossRef] [PubMed]

162. Klunk, W.E.; Bacskai, B.J.; Mathis, C.A.; Kajdasz, S.T.; McLellan, M.E.; Frosch, M.P.; Debnath, M.L.; Holt, D.P.; Wang, Y.; Hyman, B.T. Imaging A $\beta$ plaques in living transgenic mice with multiphoton microscopy and methoxy-X04, a systemically administered Congo red derivative. J. Neuropathol. Exp. Neurol. 2002, 61, 797-805. [CrossRef] [PubMed]

163. Koffie, R.M.; Meyer-Luehmann, M.; Hashimoto, T.; Adams, K.W.; Mielke, M.L.; Garcia-Alloza, M.; Micheva, K.D.; Smith, S.J.; Kim, M.L.; Lee, V.M.; et al. Oligomeric amyloid $\beta$ associates with postsynaptic densities and correlates with excitatory synapse loss near senile plaques. Proc. Natl. Acad. Sci. USA 2009, 106, 4012-4017. [CrossRef] [PubMed]

164. Lee, E.B.; Leng, L.Z.; Zhang, B.; Kwong, L.; Trojanowski, J.Q.; Abel, T.; Lee, V.M. Targeting amyloid- $\beta$ peptide $(\mathrm{A} \beta)$ oligomers by passive immunization with a conformation-selective monoclonal antibody improves learning and memory in A $\beta$ precursor protein (APP) transgenic mice. J. Biol. Chem. 2006, 281, 4292-4299. [CrossRef] [PubMed]

165. Gudiksen, K.L.; Gitlin, I.; Whitesides, G.M. Differentiation of proteins based on characteristic patterns of association and denaturation in solutions of SDS. Proc. Natl. Acad. Sci. USA 2006, 103, 7968-7972. [CrossRef] [PubMed]

166. Leffers, K.W.; Schell, J.; Jansen, K.; Lucassen, R.; Kaimann, T.; Nagel-Steger, L.; Tatzelt, J.; Riesner, D. The structural transition of the prion protein into its pathogenic conformation is induced by unmasking hydrophobic sites. J. Mol. Biol. 2004, 344, 839-853. [CrossRef] [PubMed] 
167. Kawooya, J.K.; Emmons, T.L.; Gonzalez-DeWhitt, P.A.; Camp, M.C.; D'Andrea, S.C. Electrophoretic mobility of Alzheimer's amyloid- $\beta$ peptides in urea-sodium dodecyl sulfate-polyacrylamide gel electrophoresis. Anal. Biochem. 2003, 323, 103-113. [CrossRef] [PubMed]

168. Montserret, R.; McLeish, M.J.; Böckmann, A.; Geourjon, C.; Penin, F. Involvement of electrostatic interactions in the mechanism of peptide folding induced by sodium dodecyl sulfate binding. Biochemistry 2000, 39, 8362-8373. [CrossRef] [PubMed]

169. Yamamoto, S.; Hasegawa, K.; Yamaguchi, I.; Tsutsumi, S.; Kardos, J.; Goto, Y.; Gejyo, F.; Naiki, H. Low concentrations of sodium dodecyl sulfate induce the extension of $\beta_{2}$-microglobulin-related amyloid fibrils at a neutral pH. Biochemistry 2004, 43, 11075-11082. [CrossRef] [PubMed]

170. Rangachari, V.; Moore, B.D.; Reed, D.K.; Sonoda, L.K.; Bridges, A.W.; Conboy, E.; Hartigan, D.; Rosenberry, T.L. Amyloid- $\beta(1-42)$ rapidly forms protofibrils and oligomers by distinct pathways in low concentrations of sodium dodecylsulfate. Biochemistry 2007, 46, 12451-12462. [CrossRef] [PubMed]

171. Rangachari, V.; Reed, D.K.; Moore, B.D.; Rosenberry, T.L. Secondary structure and interfacial aggregation of amyloid- $\beta(1-40)$ on sodium dodecyl sulfate micelles. Biochemistry 2006, 45, 8639-8648. [CrossRef] [PubMed]

172. Piening, N.; Weber, P.; Högen, T.; Beekes, M.; Kretzschmar, H.; Giese, A. Photo-induced crosslinking of prion protein oligomers and prions. Amyloid 2006, 13, 67-77. [CrossRef] [PubMed]

173. Moussa, C.E.; Wersinger, C.; Rusnak, M.; Tomita, Y.; Sidhu, A. Abnormal migration of human wild-type $\alpha$-synuclein upon gel electrophoresis. Neurosci. Lett. 2004, 371, 239-243. [CrossRef] [PubMed]

174. Podlisny, M.B.; Ostaszewski, B.L.; Squazzo, S.L.; Koo, E.H.; Rydell, R.E.; Teplow, D.B.; Selkoe, D.J. Aggregation of secreted amyloid $\beta$-protein into sodium dodecyl sulfate-stable oligomers in cell culture. J. Biol. Chem. 1995, 270, 9564-9570. [CrossRef] [PubMed]

175. Walsh, D.M.; Hartley, D.M.; Kusumoto, Y.; Fezoui, Y.; Condron, M.M.; Lomakin, A.; Benedek, G.B.; Selkoe, D.J.; Teplow, D.B. Amyloid $\beta$-protein fibrillogenesis. Structure and biological activity of protofibrillar intermediates. J. Biol. Chem. 1999, 274, 25945-25952. [CrossRef] [PubMed]

176. Mori, H.; Takio, K.; Ogawara, M.; Selkoe, D.J. Mass spectrometry of purified amyloid $\beta$ protein in Alzheimer's disease. J. Biol. Chem. 1992, 267, 17082-17086. [PubMed]

177. Yu, L.; Edalji, R.; Harlan, J.E.; Holzman, T.F.; Lopez, A.P.; Labkovsky, B.; Hillen, H.; Barghorn, S.; Ebert, U.; Richardson, P.L.; et al. Structural characterization of a soluble amyloid $\beta$-peptide oligomer. Biochemistry 2009, 48, 1870-1877. [CrossRef] [PubMed]

178. Barghorn, S.; Nimmrich, V.; Striebinger, A.; Krantz, C.; Keller, P.; Janson, B.; Bahr, M.; Schmidt, M.; Bitner, R.S.; Harlan, J.; et al. Globular amyloid $\beta$-peptide $1-42$ oligomer-A homogenous and stable neuropathological protein in Alzheimer's disease. J. Neurochem. 2005, 95, 834-847. [CrossRef] [PubMed]

179. Bitan, G.; Kirkitadze, M.D.; Lomakin, A.; Vollers, S.S.; Benedek, G.B.; Teplow, D.B. Amyloid $\beta$-protein (A $\beta$ ) assembly: $A \beta 40$ and $A \beta 42$ oligomerize through distinct pathways. Proc. Natl. Acad. Sci. USA 2003, 100, 330-335. [CrossRef] [PubMed]

180. Bitan, G.; Tarus, B.; Vollers, S.S.; Lashuel, H.A.; Condron, M.M.; Straub, J.E.; Teplow, D.B. A molecular switch in amyloid assembly: Met $^{35}$ and amyloid $\beta$-protein oligomerization. J. Am. Chem. Soc. 2003, 125, 15359-15365. [CrossRef] [PubMed]

181. Hepler, R.W.; Grimm, K.M.; Nahas, D.D.; Breese, R.; Dodson, E.C.; Acton, P.; Keller, P.M.; Yeager, M.; Wang, H.; Shughrue, P.; et al. Solution state characterization of amyloid $\beta$-derived diffusible ligands. Biochemistry 2006, 45, 15157-15167. [CrossRef] [PubMed]

182. O’Nuallain, B.; Freir, D.B.; Nicoll, A.J.; Risse, E.; Ferguson, N.; Herron, C.E.; Collinge, J.; Walsh, D.M. Amyloid $\beta$-protein dimers rapidly form stable synaptotoxic protofibrils. J. Neurosci. 2010, 30, 14411-14419. [CrossRef] [PubMed]

183. Watt, A.D.; Perez, K.A.; Rembach, A.; Sherrat, N.A.; Hung, L.W.; Johanssen, T.; McLean, C.A.; Kok, W.M.; Hutton, C.A.; Fodero-Tavoletti, M.; et al. Oligomers, fact or artefact? SDS-PAGE induces dimerization of $\beta$-amyloid in human brain samples. Acta Neuropathol. 2013, 125, 549-564. [CrossRef] [PubMed]

184. Pujol-Pina, R.; Vilaprinyó-Pascual, S.; Mazzucato, R.; Arcella, A.; Vilaseca, M.; Orozco, M.; Carulla, N. SDS-PAGE analysis of $\mathrm{A} \beta$ oligomers is disserving research into Alzheimer s disease: Appealing for ESI-IM-MS. Sci. Rep. 2015, 5, 14809. [CrossRef] [PubMed]

185. Bitan, G.; Vollers, S.S.; Teplow, D.B. Elucidation of primary structure elements controlling early amyloid $\beta$-protein oligomerization. J. Biol. Chem. 2003, 278, 34882-34889. [CrossRef] [PubMed] 
186. Dahlgren, K.N.; Manelli, A.M.; Stine, W.B., Jr.; Baker, L.K.; Krafft, G.A.; LaDu, M.J. Oligomeric and fibrillar species of amyloid- $\beta$ peptides differentially affect neuronal viability. J. Biol. Chem. 2002, 277, 32046-32053. [CrossRef] [PubMed]

187. Vasilevko, V.; Pop, V.; Kim, H.J.; Saing, T.; Glabe, C.C.; Milton, S.; Barrett, E.G.; Cotman, C.W.; Cribbs, D.H.; Head, E. Linear and conformation specific antibodies in aged beagles after prolonged vaccination with aggregated Abeta. Neurobiol. Dis. 2010, 39, 301-310. [CrossRef] [PubMed]

188. Head, E.; Pop, V.; Vasilevko, V.; Hill, M.; Saing, T.; Sarsoza, F.; Nistor, M.; Christie, L.A.; Milton, S.; Glabe, C.; et al. A two-year study with fibrillar $\beta$-amyloid $(A \beta)$ immunization in aged canines: Effects on cognitive function and brain A $\beta$. J. Neurosci. 2008, 28, 3555-3566. [CrossRef] [PubMed]

189. Galzitskaya, O.V. Repeats are one of the main characteristics of RNA-binding proteins with prion-like domains. Mol. Biosyst. 2015, 11, 2210-2218. [CrossRef] [PubMed]

190. Calamai, M.; Kumita, J.R.; Mifsud, J.; Parrini, C.; Ramazzotti, M.; Ramponi, G.; Taddei, N.; Chiti, F.; Dobson, C.M. Nature and significance of the interactions between amyloid fibrils and biological polyelectrolytes. Biochemistry 2006, 45, 12806-12815. [CrossRef] [PubMed]

191. Maury, C.P. The emerging concept of functional amyloid. J. Intern. Med. 2009, 265, 329-334. [CrossRef] [PubMed]

192. Sharon, R.; Bar-Joseph, I.; Frosch, M.P.; Walsh, D.M.; Hamilton, J.A.; Selkoe, D.J. The formation of highly soluble oligomers of $\alpha$-synuclein is regulated by fatty acids and enhanced in Parkinson's disease. Neuron 2003, 37, 583-595. [CrossRef]

193. Lesné, S.; Koh, M.T.; Kotilinek, L.; Kayed, R.; Glabe, C.G.; Yang, A.; Gallagher, M.; Ashe, K.H. A specific amyloid- $\beta$ protein assembly in the brain impairs memory. Nature 2006, 440, 352-357. [CrossRef] [PubMed]

194. Klucken, J.; Ingelsson, M.; Shin, Y.; Irizarry, M.C.; Hedley-Whyte, E.T.; Frosch, M.; Growdon, J.; McLean, P.; Hyman, B.T. Clinical and biochemical correlates of insoluble $\alpha$-synuclein in dementia with Lewy bodies. Acta Neuropathol. 2006, 111, 101-108. [CrossRef] [PubMed]

195. Shankar, G.M.; Bloodgood, B.L.; Townsend, M.; Walsh, D.M.; Selkoe, D.J.; Sabatini, B.L. Natural oligomers of the Alzheimer amyloid- $\beta$ protein induce reversible synapse loss by modulating an NMDA-type glutamate receptor-dependent signaling pathway. J. Neurosci. 2007, 27, 2866-2875. [CrossRef] [PubMed]

196. Shankar, G.M.; Li, S.; Mehta, T.H.; Garcia-Munoz, A.; Shepardson, N.E.; Smith, I.; Brett, F.M.; Farrell, M.A.; Rowan, M.J.; Lemere, C.A.; et al. Amyloid- $\beta$ protein dimers isolated directly from Alzheimer's brains impair synaptic plasticity and memory. Nat. Med. 2008, 14, 837-842. [CrossRef] [PubMed]

197. Paleologou, K.E.; Kragh, C.L.; Mann, D.M.; Salem, S.A.; Al-Shami, R.; Allsop, D.; Hassan, A.H.; Jensen, P.H.; El-Agnaf, O.M. Detection of elevated levels of soluble $\alpha$-synuclein oligomers in post-mortem brain extracts from patients with dementia with Lewy bodies. Brain 2009, 132, 1093-1101. [CrossRef] [PubMed]

198. Head, E.; Pop, V.; Sarsoza, F.; Kayed, R.; Beckett, T.L.; Studzinski, C.M.; Tomic, J.L.; Glabe, C.G.; Murphy, M.P. Amyloid- $\beta$ peptide and oligomers in the brain and cerebrospinal fluid of aged canines. J. Alzheimers Dis. 2010, 20, 637-646. [CrossRef] [PubMed]

199. Ono, K.; Condron, M.M.; Teplow, D.B. Structure-neurotoxicity relationships of amyloid $\beta$-protein oligomers. Proc. Natl. Acad. Sci. USA 2009, 106, 14745-14750. [CrossRef] [PubMed]

200. Qu, J.; Yu, S.; Zheng, Y.; Zheng, Y.; Yang, H.; Zhang, J. Aptamer and its applications in neurodegenerative diseases. Cell. Mol. Life Sci. 2017, 74, 683-695. [CrossRef] [PubMed]

201. Röthlisberger, P.; Gasse, C.; Hollenstein, M. Nucleic acid aptamers: Emerging applications in medical imaging, nanotechnology, neurosciences, and drug delivery. Int. J. Mol. Sci. 2017, 18, 2430. [CrossRef] [PubMed]

202. Sriramoju, B.; Kanwar, R.; Veedu, R.N.; Kanwar, J.R. Aptamer-targeted oligonucleotide theranostics: A smarter approach for brain delivery and the treatment of neurological diseases. Curr. Top. Med. Chem. 2015, 15, 1115-1124. [CrossRef] [PubMed]

(C) 2018 by the author. Licensee MDPI, Basel, Switzerland. This article is an open access article distributed under the terms and conditions of the Creative Commons Attribution (CC BY) license (http:/ / creativecommons.org/licenses/by/4.0/). 